Review

\title{
Perspectives for Recognition and Rapid Detection of Foodborne Pathogenic Bacteria Based on Electrochemical Sensors
}

\author{
Yahui Wang ${ }^{2}$, Xin $\mathrm{Ma}^{1}$, Xiujuan Qiao' ${ }^{2}$, Pingping Yang ${ }^{2}$, Qinglin Sheng ${ }^{1,2, *}$, Ming Zhou ${ }^{3, *}$, Tianli Yue ${ }^{1, *}$ \\ ${ }^{1}$ College of Food Science and Technology, Northwest University, Laboratory of Nutritional and Healthy Food-Individuation Manufacturing \\ Engineering/Research Center of Food Safety Risk Assessment and Control, Xian, Shaanxi 710069, China \\ ${ }^{2}$ College of Chemistry \& Materials Science/Key Laboratory of Synthetic and Natural Functional Molecule Chemistry of Ministry of \\ Education/Shaanxi Provincial Key Laboratory of Electroanalytical Chemistry, Northwest University, Xian, Shaanxi 710069, China \\ ${ }^{3}$ Key Laboratory of Nanobiosensing and Nanobioanalysis at Universities of Jilin Province, Key Laboratory of Polyoxometalate Science of Ministry \\ of Education, Faculty of Chemistry, and National \& Local United Engineering Laboratory for Power Batteries, Department of Chemistry, \\ Northeast Normal University, Changchun, Jilin 130024, China
}

\section{ARTICLE INFO}

Article History

Received 13 April 2021

Accepted 18 June 2021

Keywords

Food safety

foodborne pathogenic bacteria recognition

rapid detection

electrochemical sensor

signal amplification

\section{ABSTRACT}

Due to the misuse of pathogen-infected food, human beings continue to face serious diseases and even deaths. Thus, researchers from all walks of life concern on prevention, detection, and resistance for pathogenic bacteria. It is necessary to develop and explore a fast, cost-effective, portable, and efficient detection technology for pathogens. Recently, electrochemical sensors have been widely used for food safety analysis, due to their increasingly high sensitivity and selectivity. In particular, researchers have made significant breakthroughs on signal enhancement strategies, quantitative methods, and miniaturization of the instrument, which can be used as a reference to food safety analysis. Moreover, a device integrating facile working procedures, miniaturization, and automation must be indispensable. In order to meet the needs of People's Daily life, household device and point-of-care (POC) testing need to be combined with electrochemical sensing technology. In this review, the state of the art in electrochemical sensing for recognition and rapid detection of foodborne pathogenic bacteria is summarized from perspectives of common foodborne pathogens, especially focusing on real-time monitoring, lab-on-a-chip, and photoelectrochemical platform applied in food and medical treatment fields. Furthermore, the limitations and prospects of recognition elements, active nanomaterials, and optical materials, that are essential components in sensing systems on future research directions, were evaluated.

\section{GRAPHICAL ABSTRACT}

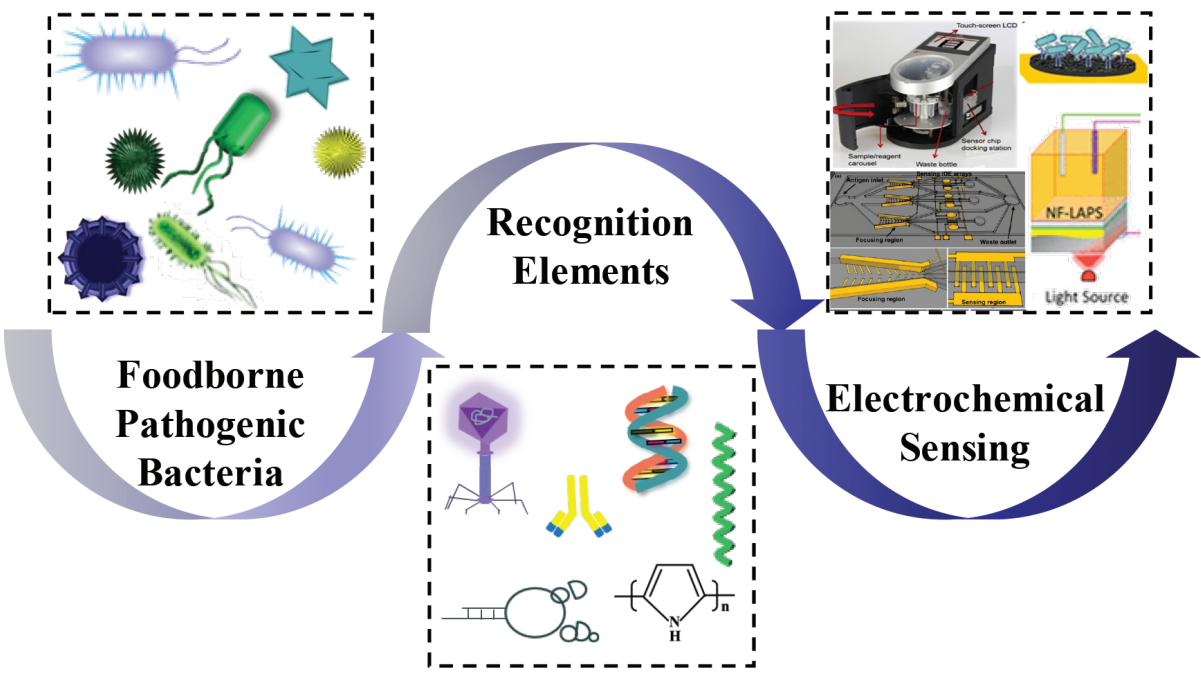

(C) 2021 The Authors. Publishing services by Atlantis Press International B.V This is an open access article distributed under the CC BY-NC 4.0 license (http://creativecommons.org/licenses/by-nc/4.0/) 


\section{INTRODUCTION}

Foodborne disease caused by human ingestion of pathogens infected food is the main sources of food safety problems. Pathogenic bacteria that cause foodborne disease are Escherichia coli (E. coli), Salmonella spp., Staphylococcus aureus (S. aureus), Listeria monocytogenes ( $\mathrm{Lm}$ ), Campylobacter spp., Clostridium botulinum, Shiga toxin-producing Escherichia coli and Enterobacter sakazakii $[1,2]$. The main symptoms of foodborne pathogens on the human body are dysentery, food poisoning, diarrhea and even death [3]. Annually, the number of deaths from bacterial infection is extremely high, with the prediction of 13 million deaths in 2050 all over the world [4]. Especially in the USA, the most commonly reported foodborne pathogenic bacteria are responsible for more than $91 \%$ of foodborne outbreaks [5]. Therefore, it is of great significance in recognition and sensitive detection of foodborne pathogenic bacteria.

Conventional culturing methods, immunological analyses, and nucleic acid-based techniques are known as main methods for detection of foodborne pathogenic bacteria. The complicated culturing method is to identify the colonies through biochemical and serological testing under strict culture conditions [6]. Although the culture technique has long been regarded as the gold standard method, its specificity is poorer than that of the antibody-antigen binding based immunoassay [7]. At present, there are some drawbacks in immunological techniques, such as time consumption operation complication (5-6 days) and limited information, namely failing to discriminate species [8-10]. Subsequently, nucleic acidbased techniques relied on deoxyribonucleic acid (DNA) probe have been widely accepted owing to these merits of high specificity and sensitivity. Despite nucleic acid-based methods provide significant application, the presence of inhibitors, misidentification of dead and living cells, expensive equipment and reagents can arise some problems [9]. Overall, traditional methods could not make a timely response to possible risks, even though these technologies have some advantages. Consequently, there is an urgent need for developing and exploring technologies addressing food safety issues.

In recent years, researchers have made some good achievements by fluorescence, chromatography, mass spectrometry, and electrochemical methods to detect pathogens [11-13]. Among these methods, electrochemical methods are among the most promising candidates for the detection of pathogenic bacteria in a low-cost, highly sensitive and selective manner [14]. However, it remains a challenge for rapid and cost-efficient detection of foodborne pathogens. So far, there has been made major breakthroughs in the field of pathogen assays with the emergence of new technologies. Electrochemical collision sensor has been applied to determine live cell viability that can oxidize or reduce redox species to decrease diffusion current of the ultramicroelectrode [15]. The sensor is suitable for monitoring cancerous cells in biological solution and evaluating the validity of antimicrobial agents. In addition, researchers developed a portable sensing platform including antibody capturing cell and impedance analysis unit [16]. The loop-mediated isothermal amplification (LAMP)-based lab-on-a-disc technology could detect a concentration of $1 \mathrm{CFU} / \mathrm{mL}$. In addition to the theoretical and semi-theoretical sensors, the number of POC and commercial kits is undeniably increasing $[17,18]$. These devices are more inseparable from electrochemical sensing technology $[19,20]$.
Furthermore, innovative, efficient, and commercial equipment must be a durative goal.

Inspired by the content mentioned above, it is intensively expected to develop a miniature, intelligent, integrated, commercial, ultrasensitive, and super-specific device until the realization of full automation. Therefore, this paper reviews the advancements of electrochemical detection for pathogenic bacteria in two parts: (1) Recognition elements and electrochemical methods-based sensors, (2) Electrochemical sensors for detection of various foodborne pathogenic bacteria emphasizing real-time monitoring, microfluidic and automated devices. Moreover, the future research direction and long-term forecast for pathogenic bacteria are discussed.

\section{RECOGNITION ELEMENTS AND ELECTROCHEMICAL METHODS-BASED SENSORS}

Electrochemical sensor has attracted public attention due to quantitative determination of foodborne pathogen bacteria and prevention of foodborne diseases. One basic electrochemistry sensor includes the recognition elements with high specificity and electrochemical detection methods with high sensitivity [21]. The basic principle of electrochemical sensing pathogen bacteria is presented in Scheme 1. The most important procedure in the preparation of sensors is surface modification including adsorption, self-assembled monolayers (SAM), covalent attachment, and imprinting [4]. The biochemical reaction on the surface of electrode can change the physical parameters such as $\mathrm{pH}$, ion concentrations, oxygen consumption, potential difference, resistance or current. Changes in physical parameters can be represented as electrical signals obtained by electrochemical analysis instruments. These changes are related to the concentration of analytes.

As an essential factor to improve specificity of the sensing system, recognition elements mainly consist of purely natural substances and artificial composites. Natural recognition elements include antibodies, DNA probes, enzymes, antimicrobial peptide (AMPs), phages, cells, and tissues. And artificial recognition elements such as aptamers, bacteria-imprinted polymers (BIP) film and synthetic peptides could capture target bacteria [22]. Moreover, BIP film is favored because of its superior electrical conductivity than other bioreceptors. The specific binding of bioreceptor to the pathogen must be independent of the substrate of actual sample.

After the modification of working electrode, electrochemical measurements such as differential pulse voltammetry (DPV), electrical impedance spectroscopy (EIS), amperometry, cyclic voltammetry (CV), square wave voltammetry (SWV), amperometry, and conductometry are used to highly sensitive detection of pathogens. Generally, electrochemical sensing is performed using two (reference and working electrodes) or three electrodes (auxiliary, reference and working electrodes) [22]. To date, various working electrodes such as screen-printed carbon electrodes (SPCE), laser-induced graphene (LIG) electrodes and microarray electrodes have been used to sensitively detect foodborne pathogen bacteria [23-25]. Additionally, the use of triple-helix DNA and amplification reactions also could improve the sensitivity of the sensor [26]. 


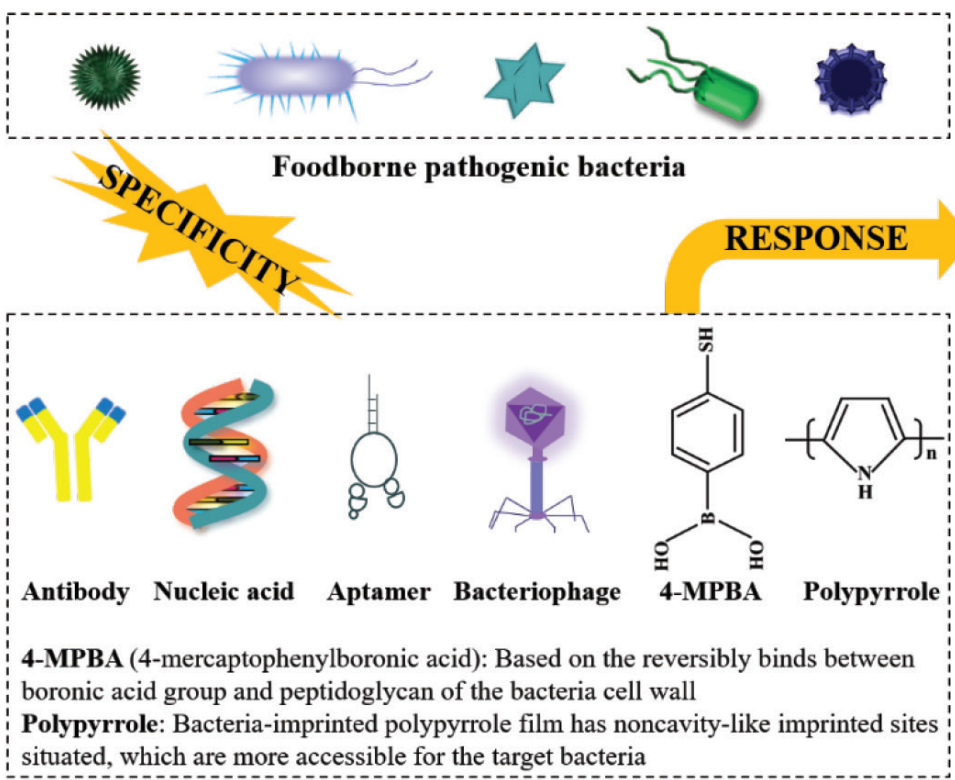

Recognition elements

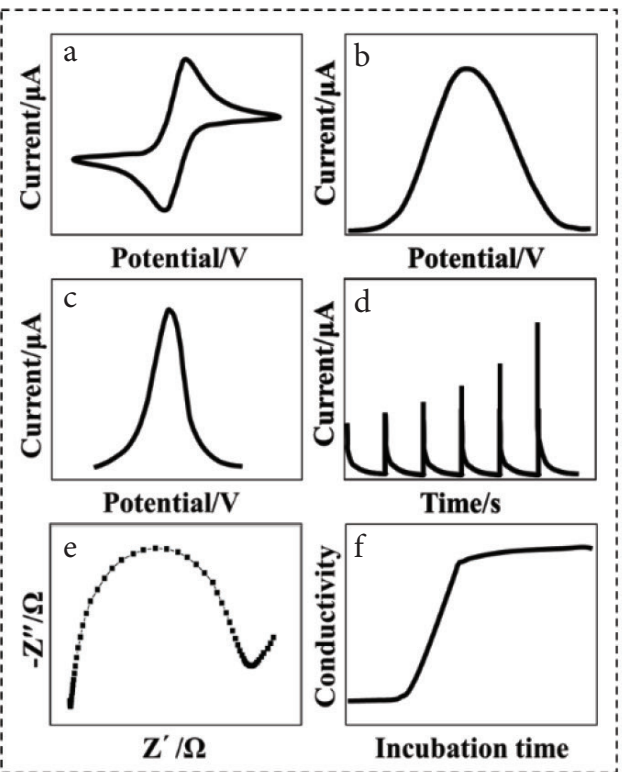

Electrochemical methods

Scheme 1 Illustration of electrochemical sensors for recognition and detection of foodborne pathogenic bacteria (a-f: CV, DPV, SWV, amperometry, EIS, conductometry).

Based on enhancing the sensitivity and selectivity of electrochemical pathogen sensors, researchers have focused on the design of functional integrated platforms and portable devices. Microfluidic device has integrated pretreatment unit, capture unit and detection unit $[27,28]$. There is no doubt that the use of microfluidic devices simplifies the actual sample pretreatment process. However, current electrochemical pathogen sensors still require pretreatment steps to analyze actual samples, except for juice [29]. So far, a few microfluidic devices have applied for outdoor analysis and clinical diagnosis [30]. Therefore, there are still hot topics related to the simplification of sample pretreatment steps and the commercialization of devices in the practical application of electrochemical sensors to detect foodborne pathogens.

\section{ELECTROCHEMICAL SENSORS FOR DETECTION OF FOODBORNE PATHOGENIC BACTERIA}

This section mainly offers a mini-review of the latest publications focusing on electrochemical sensor for the detection of multiple foodborne pathogenic bacteria, especially on E. coli, Salmonella, $S$. aureus, $L m$ and other bacteria. Our goal is to review bacterial research regarding electrochemical sensing and to get the up-todate knowledge of this innovative detection method. Therefore, electrochemical sensors for the detection of different pathogenic bacteria are summarized in Tables 1-5. Furthermore, the sensing system (detection methods, modified electrodes, recognition elements), linear ranges and limit of detection (LOD) are given. It should be noted that only a few electrochemical sensors could detect pathogenic bacteria as low as $1 \mathrm{CFU} / \mathrm{mL}$ (colony forming units) or $5 \mathrm{fM}$ (DNA). A great deal of nano(bio)-materials and conductive polymer films with favorable chemical, physical and biological properties are currently used for the construction of modified electrodes.

\subsection{Electrochemical Sensors for Detection of Escherichia coli}

As an important member of the intestinal ecosystem of mammals including humans, E. coli is contributing to the synthesis vitamin K2 in human body. Nonetheless, a number of pathogenic strains has caused the formation of distinct pathotypes in urinary tract and gastrointestinal tract to cause regional diseases. There are three general clinical syndromes such as diarrhea, sepsis and meningitis [31]. Thereinto, diarrheal illnesses are a major cause of morbidity and mortality in infants and young children in Africa, Asia and Latin America [32]. Thus, it is urgent to monitor E. coli especially in food.

A two-dimensional poly-adenine (poly A) probe was used to set up a "sandwich-type" chronocoulometric biosensor [33]. The poly A probe consisted of recognition block which can specifically capture the target DNA (tDNA) through hybridization and poly A anchoring block (a short oligo of five consecutive adenines) which can form the strong combination between poly A and Au electrode surface. Subsequently, the biotin-labeled reporter probe can bind to avidin horseradish peroxidase (HRP), producing an enzyme catalytic signal that was correlated with the amount of tDNA (Figure 1A). The biosensor was able to detect a lower concentration of $5 \mathrm{fM}$ for $E$. coli DNA. The density changes of the probes by adjusting the length of poly can optimize the electrontransfer effect and further the hybridization efficiency. This device has potential applications on the spot analysis towards pathogenic bacteria in a highly stable, reusable, practical, and lowcost manner. Additionally, polypyrrole is regarded as the most potential conductive polymer applied in electrochemical sensor, due to its high specific adsorption, good stability, advantageous conductivity, and efficient polymerization at mild conditions. BIP film has been successfully fabricated for impedimetric detection of pathogens (Figure 1B) [34]. The noncavity-like imprinted 
Table 1 Overview of electrochemical sensors to detect E. coli

\begin{tabular}{|c|c|c|c|c|c|c|}
\hline Detection method & Modified electrode & $\begin{array}{l}\text { Biorecognition } \\
\text { element }\end{array}$ & Analyte & Linear range & LOD & References \\
\hline EIS & ITO/MWCNT/PEI & Antibody & E. coli $\mathrm{O} 157: \mathrm{H} 7$ & $1-10^{4} \mathrm{CFU} / \mathrm{mL}$ & $1 \mathrm{CFU} / \mathrm{mL}$ & [16] \\
\hline EIS \& SPR & $\begin{array}{l}\text { Au interdigitated } \\
\text { microelectrodes }\end{array}$ & Antibody & E. coli $\mathrm{K} 12$ & $10^{3}-10^{6} \mathrm{CFU} / \mathrm{mL}$ & $10^{3} \mathrm{CFU} / \mathrm{mL}$ & {$[70]$} \\
\hline EIS & MNPs-Ag/SPIDE & Melittin & E. coli & $1-10^{6} \mathrm{CFU} / \mathrm{mL}$ & $1 \mathrm{CFU} / \mathrm{mL}$ & [71] \\
\hline EIS & $\begin{array}{l}\text { Interdigitated } \\
\text { microelectrode }\end{array}$ & $\begin{array}{l}\text { Antibody and } \\
\text { aptamer }\end{array}$ & E. coli $\mathrm{O} 157: \mathrm{H7}$ & $10-10^{5} \mathrm{CFU} / \mathrm{mL}$ & $12 \mathrm{CFU} / \mathrm{mL}$ & {$[25]$} \\
\hline EIS & BIP/GCE & $\begin{array}{l}\text { Recognition sites } \\
\text { on the BIP film }\end{array}$ & E. coli $\mathrm{O} 157: \mathrm{H} 7$ & $\geq 10^{3} \mathrm{CFU} / \mathrm{mL}$ & $10^{3} \mathrm{CFU} / \mathrm{mL}$ & {$[34]$} \\
\hline Amperometry & Au chip (8 Au electrodes) & Antibody & E. coli & $10-3.97 \times 10^{7} \mathrm{CFU} / \mathrm{mL}$ & $50 \mathrm{CFU} / \mathrm{mL}$ & [27] \\
\hline EIS & TSP/Au electrode & DNA & E. coli genome & - & $10 \mathrm{fM}$ synthetic DNA & [72] \\
\hline Chronocoulometry & $\begin{array}{l}\text { Au electrode/poly A } \\
\text { probe/tDNA/reporter } \\
\text { probe }\end{array}$ & Poly A probe & E. coli genome & - & $5 \mathrm{fM}$ synthetic DNA & [33] \\
\hline LAPS & Hydrogel nanofibers-Si chip & D-mannose & E. coli & - & $10^{2} \mathrm{CFU} / \mathrm{mL}$ & [29] \\
\hline Amperometry & PB-modified SPIMs & Enzyme & E. coli $\mathrm{O} 157: \mathrm{H7}$ & $10-10^{6} \mathrm{CFU} / \mathrm{mL}$ & $10^{2} \mathrm{CFU} / \mathrm{mL}$ & [73] \\
\hline EIS & $\begin{array}{l}\text { Bridged rebar graphene } \\
\text { SPCE }\end{array}$ & Aptamer & E. coli $\mathrm{O} 78: \mathrm{K} 80: \mathrm{H} 11$ & $\begin{array}{l}10-10^{6} \mathrm{CFU} / \mathrm{mL} \\
\left(\mathrm{H}_{2} \mathrm{O}, \text { milk, juice }\right)\end{array}$ & $10 \mathrm{CFU} / \mathrm{mL}$ & [23] \\
\hline EIS & 3D-IDEA & Aptamer & E. coli $\mathrm{O} 157: \mathrm{H} 7$ & $10-10^{5} \mathrm{CFU} / \mathrm{mL}$ & $2.9 \times 10^{2} \mathrm{CFU} / \mathrm{mL}$ & [74] \\
\hline
\end{tabular}

ITO, indium tin oxide; CFU (colony forming units), the single colony consists of many bacterial cells which may have started from one cell or a group of cells; SPR, surface plasmon resonance; MNPs, magnetic nanoparticles; SPIDE, screen-printed interdigitated electrodes; GCE, glassy carbon electrode; TSP, tetrahedral structure probes; PB-modified SPIMS, prussian blue-modified screen printed-interdigitated microelectrodes; 3D-IDEA, three-dimensional interdigitated electrode array.

Table 2 Summary of electrochemical sensors to detect Salmonella

\begin{tabular}{|c|c|c|c|c|c|c|}
\hline Detection method & Modified electrode & $\begin{array}{l}\text { Biorecognition } \\
\text { element }\end{array}$ & Analyte & Linear range & LOD & References \\
\hline EIS & NPG/GCE & Aptamer & S. typhi & $\begin{array}{l}6.5 \times 10^{2}-6.5 \times 10^{8} \\
\mathrm{CFU} / \mathrm{mL}\end{array}$ & $1 \mathrm{CFU} / \mathrm{mL}$ & [75] \\
\hline Potentiometry & ssDNA/MWCNT/ITO & Aptamer & S. typhi & $\begin{array}{c}67-6.7 \times 10^{5} \\
\mathrm{CFU} / \mathrm{mL}\end{array}$ & $10 \mathrm{CFU} / \mathrm{mL}$ & [14] \\
\hline EIS & MNPs/Ag SPIMs & Melittin & S. typhi & $10-10^{4} \mathrm{CFU} / \mathrm{mL}$ & $10 \mathrm{CFU} / \mathrm{mL}$ & [71] \\
\hline EIS & Mannose/MUA/Au electrode & Mannose & Salmonella ATC14028 & $50-10^{3} \mathrm{CFU} / \mathrm{mL}$ & $50 \mathrm{CFU} / \mathrm{mL}$ & [76] \\
\hline EIS & SAM/Au-SPEs & Antibody & S. typhi & $10^{3}-10^{7} \mathrm{CFU} / \mathrm{mL}$ & - & [77] \\
\hline DPV & $\begin{array}{l}\text { AuNPs-HRP-streptavidin/ } \\
\text { biotin-DNA/tDNA/cDNA/ } \\
\text { AuNPs/PPy-RGO/GCE }\end{array}$ & DNA & Salmonella & $9.6-9.6 \times 10^{4} \mathrm{CFU} / \mathrm{mL}$ & $8.07 \mathrm{CFU} / \mathrm{mL}$ & [78] \\
\hline DPV & 8 -electrodes array & Antibody & S. typhi & $10-10^{2}$ cells $/ \mathrm{mL}$ & 7.7 cells $/ \mathrm{mL}$ & [43] \\
\hline EIS & Interdigitated electrode array & Antibody & Salmonella serogroups & - & 7 cells/mL & [44] \\
\hline Electrical signal-off & Two gold electrodes & Antibody & S. typhi & $37-3.7 \times 10^{6} \mathrm{CFU} / \mathrm{mL}$ & $33 \mathrm{CFU} / \mathrm{mL}$ & [79] \\
\hline EIS & Diazonium-grafting/SPEs & Aptamer & S. typhi & $10-10^{8} \mathrm{CFU} / \mathrm{mL}$ & $6 \mathrm{CFU} / \mathrm{mL}$ & [80] \\
\hline EIS & $\begin{array}{l}\text { Aptamer/poly [pyrrole- } \\
\text { co-3-carboxyl-pyrrole] } \\
\text { copolymer/Au disk electrode }\end{array}$ & Aptamer & S. typhi & $10^{2}-10^{8} \mathrm{CFU} / \mathrm{mL}$ & $3 \mathrm{CFU} / \mathrm{mL}$ & {$[81]$} \\
\hline EIS & $\begin{array}{l}\text { ssDNA/CeO }- \text {-nanorod@ } \\
\text { polypyrrole/microelectrode }\end{array}$ & ssDNA & Salmonella & $0.01-0.4 \mathrm{nM}$ & $0.084 \mathrm{nM}$ & [82] \\
\hline Chronoamperometry & $\begin{array}{l}\text { Antibody/cysteamine } \\
\text { monolayer and protein A/ } \\
\text { Au electrode }\end{array}$ & Antibody & S. typhi & $10-10^{6} \mathrm{CFU} / \mathrm{mL}$ & $10 \mathrm{CFU} / \mathrm{mL}$ & [83] \\
\hline EIS & RGO-MWCNT/GCE & Aptamer & Salmonella & $75-7.5 \times 10^{5} \mathrm{CFU} / \mathrm{mL}$ & $25 \mathrm{CFU} / \mathrm{mL}$ & {$[84]$} \\
\hline $\begin{array}{l}\text { Capacitance } \\
\text { measurement }\end{array}$ & $\begin{array}{l}\text { Phage/polytyramine/Au } \\
\text { electrode }\end{array}$ & Phage & Salmonella spp. & $2.0 \times 10^{2}-10^{7} \mathrm{CFU} / \mathrm{mL}$ & $2 \times 10^{2} \mathrm{CFU} / \mathrm{mL}$ & [85] \\
\hline DPV & ssDNA/RGO-TiO,/GCE & Aptamer & S. enterica serovar typhi & $10-10^{8} \mathrm{CFU} / \mathrm{mL}$ & $10 \mathrm{CFU} / \mathrm{mL}$ & [86] \\
\hline Potentiometry & $\begin{array}{l}\text { Antibody/AuNPs-PIM/pipette- } \\
\text { tip electrode }\end{array}$ & Antibody & S. typhi & $13-1.3 \times 10^{6}$ cells $/ \mathrm{mL}$ & 6 cells $/ \mathrm{mL}$ & [39] \\
\hline EIS & Nisin/Au electrode & Nisin & S. typhi & $15-1.5 \times 10^{4} \mathrm{CFU} / \mathrm{mL}$ & $15 \mathrm{CFU} / \mathrm{mL}$ & [87] \\
\hline EIS & $\begin{array}{l}\text { Antibody/laser-induced } \\
\text { graphene electrode }\end{array}$ & Antibody & S. enterica & $25-10^{5} \mathrm{CFU} / \mathrm{mL}$ & $13 \mathrm{CFU} / \mathrm{mL}$ & [24] \\
\hline EIS & Aptamer/Au microelectrode & Aptamer & S. typhi & $10^{2}-10^{6} \mathrm{CFU} / \mathrm{mL}$ & $80 \mathrm{CFU} / \mathrm{mL}$ & {$[41]$} \\
\hline DPV & Antibody/magnetic beads/SPCE & Antibody & S. typhi & $10-10^{7} \mathrm{CFU} / \mathrm{mL}$ & $3 \mathrm{CFU} / \mathrm{mL}$ & [42] \\
\hline
\end{tabular}

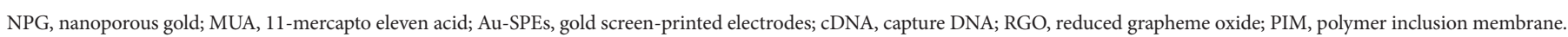


Table 3 Overview of electrochemical sensors to detect S. aureus

\begin{tabular}{|c|c|c|c|c|c|c|}
\hline $\begin{array}{l}\text { Detection } \\
\text { method }\end{array}$ & Modified electrode & $\begin{array}{l}\text { Biorecognition } \\
\text { element }\end{array}$ & Analyte & Linear range & LOD & References \\
\hline DPV & SWCNT conjugate/CPE & Antibody & S. aureus & $10-10^{7} \mathrm{CFU} / \mathrm{mL}$ & $13 \mathrm{CFU} / \mathrm{mL}$ & {$[88]$} \\
\hline EIS & AgNPs/3D-ZnO/FTO electrode & Vancomycin & S. aureus & - & $330 \mathrm{CFU} / \mathrm{mL}$ & {$[48]$} \\
\hline EIS & TSP/Au electrode & DNA & mecA gene & - & $57 \mathrm{fM}$ & [46] \\
\hline SWV & A hanging mercury drop electrode & Antibody & MRSA & $4 \times 10^{7}-2 \times 10^{4} \mathrm{CFU} / \mathrm{mL}$ & $2 \times 10^{4} \mathrm{CFU} / \mathrm{mL}$ & [89] \\
\hline DPV & Antibody-ALP/anti-PBP2a MNPs/Au electrode & Antibody & MRSA & $10^{3}-10^{5} \mathrm{CFU} / \mathrm{mL}$ & $845 \mathrm{CFU} / \mathrm{mL}$ & {$[30]$} \\
\hline DPV & Triple-helix molecular switch/Au electrode & Aptamer & S. aureus & $30-3 \times 10^{8} \mathrm{CFU} / \mathrm{mL}$ & $8 \mathrm{CFU} / \mathrm{mL}$ & [26] \\
\hline EIS & Antibody/AuNPs/GCE & Antibody & S. aureus & $10-10^{7} \mathrm{CFU} / \mathrm{mL}$ & $3.3 \mathrm{CFU} / \mathrm{mL}$ & [90] \\
\hline DPV & Phage/PEI/c-MWCNTs/BC/electrode & Phage & S. aureus & - & $3 \mathrm{CFU} / \mathrm{mL}$ & [47] \\
\hline
\end{tabular}

SWCNT, single walled carbon nanotubes; CPE, carbon paste electrode; FTO, conductive glass.

Table 4 Overview of electrochemical sensors to detect $\mathrm{Lm}$

\begin{tabular}{|c|c|c|c|c|c|c|}
\hline $\begin{array}{l}\text { Detection } \\
\text { method }\end{array}$ & Modified electrode & $\begin{array}{l}\text { Biorecognition } \\
\text { element }\end{array}$ & Analyte & Linear range & LOD & References \\
\hline EIS & Interdigitated array microelectrode & Antibody & $L m$ & $1.6 \times 10^{2}-1.6 \times 10^{5} \mathrm{CFU} / \mathrm{mL}$ & $1.6 \times 10^{2} \mathrm{CFU} / \mathrm{mL}$ & [91] \\
\hline ECL & Paper-based bipolar electrode & Nucleic acid & $L m$ & - & 10 copies $/ \mu \mathrm{L}$ & {$[53]$} \\
\hline DPV & ssDNA/RGO/AuNPs/CILE & ssDNA & $L m$ & $10^{-13}-10^{-6} \mathrm{M}$ & $3.17 \times 10^{-14} \mathrm{M}$ & [92] \\
\hline EIS & Interdigitated Au electrodes & Antibody & $\mathrm{Lm}$ & $2.2 \times 10^{3}-10^{2} \mathrm{CFU} / \mathrm{mL}$ & $5.5 \mathrm{CFU} / \mathrm{mL}$ & {$[60]$} \\
\hline EIS & $\begin{array}{l}\text { MNP(MAb)-Lm-AuNPs (urease- } \\
\text { PAb)/SPIE }\end{array}$ & Polyclonal antibody & $L m$ & $1.9 \times 10^{3}-1.9 \times 10^{6} \mathrm{CFU} / \mathrm{mL}$ & $1.6 \times 10^{3} \mathrm{CFU} / \mathrm{mL}$ & {$[59]$} \\
\hline Amperometry & $\begin{array}{l}\mathrm{H}_{2} \mathrm{O}_{2} / \mathrm{HRP} \text {-antibody/MWCNT } \\
\text { fibers electrode }\end{array}$ & Antibody & $L m$ & $10^{2}-10^{5} \mathrm{CFU} / \mathrm{mL}$ & $1.07 \times 10^{2} \mathrm{CFU} / \mathrm{mL}$ & {$[93]$} \\
\hline Amperometry & $\mathrm{AAO} / \mathrm{Au}$ electrode & Aptamer & $L m$ & $100-1250 \mathrm{CFU} / \mathrm{mL}$ & $10^{2} \mathrm{CFU} / \mathrm{mL}$ & [94] \\
\hline Amperometry & Pt electrode & $\begin{array}{l}\text { Ferric ammonium } \\
\text { citrate and esculin }\end{array}$ & $L m$ & $10^{2}-10^{8} \mathrm{CFU} / \mathrm{mL}$ & - & {$[95]$} \\
\hline LSV & $\begin{array}{l}\mathrm{Ag}^{+} / \mathrm{ALP}-\text { secondary antibody/ } \\
\text { detection antibody/targets/capture } \\
\text { antibody/SPCE }\end{array}$ & Antibody & $\begin{array}{l}L m \text { p } 60 \\
\text { proteins }\end{array}$ & - & $1.5 \mathrm{ng} / \mathrm{mL}$ & {$[96]$} \\
\hline SWV & Peptide-magnetic bead/AuNPs/SPCE & Peptide & $L m$ & - & $9 \mathrm{CFU} / \mathrm{mL}$ & {$[56]$} \\
\hline
\end{tabular}

ECL, electrochemical immunoluminescence; Copies, the number of genes (or plasmids) in the genome of a given organism; CILE, carbon ionic liquid electrode; SPIE, screen-printed interdigitated electrode; AAO, Anodic aluminum oxide; LSV, linear sweep voltammetry.

Table 5 Overview of electrochemical sensors to detect other bacteria

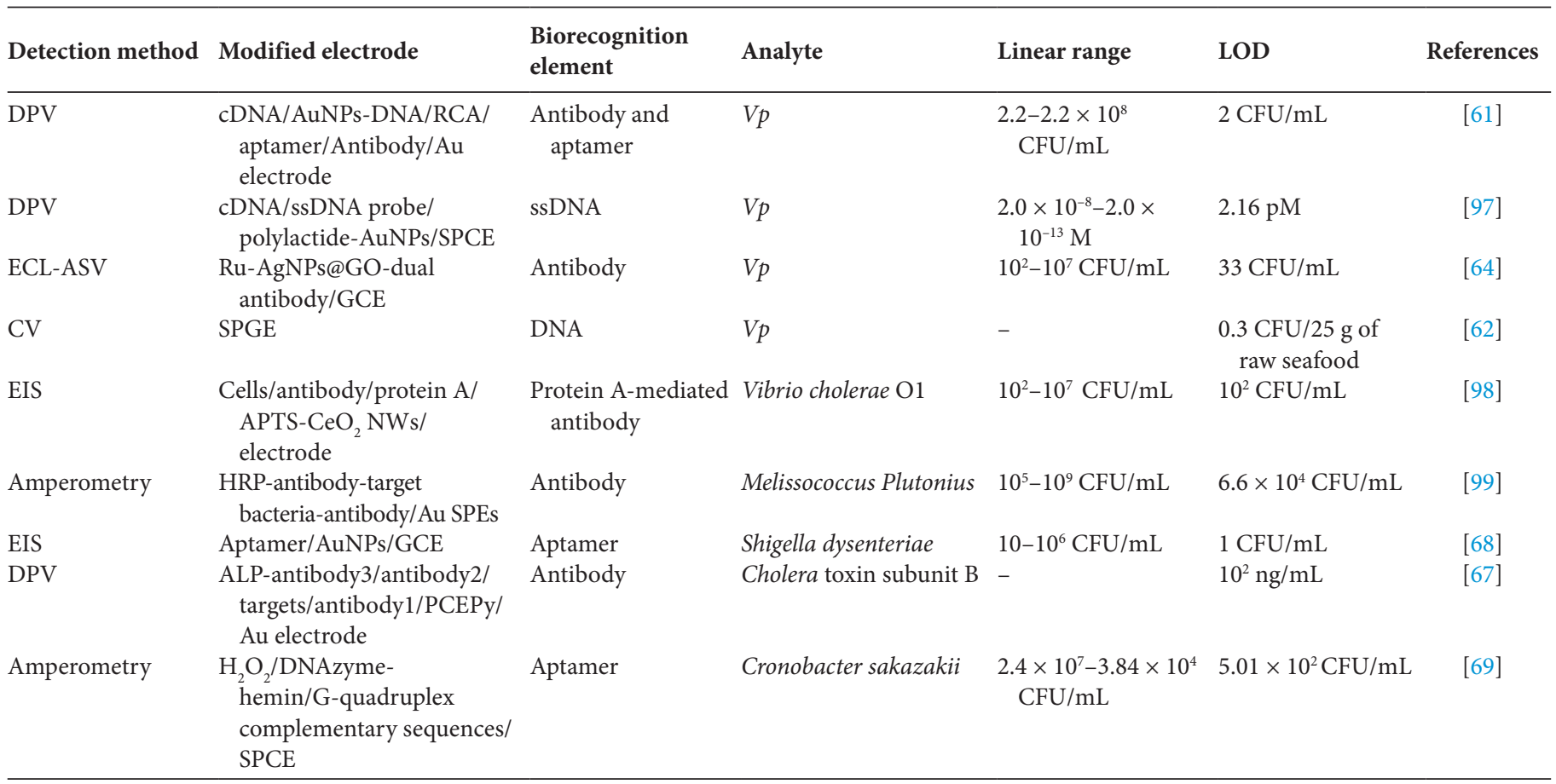



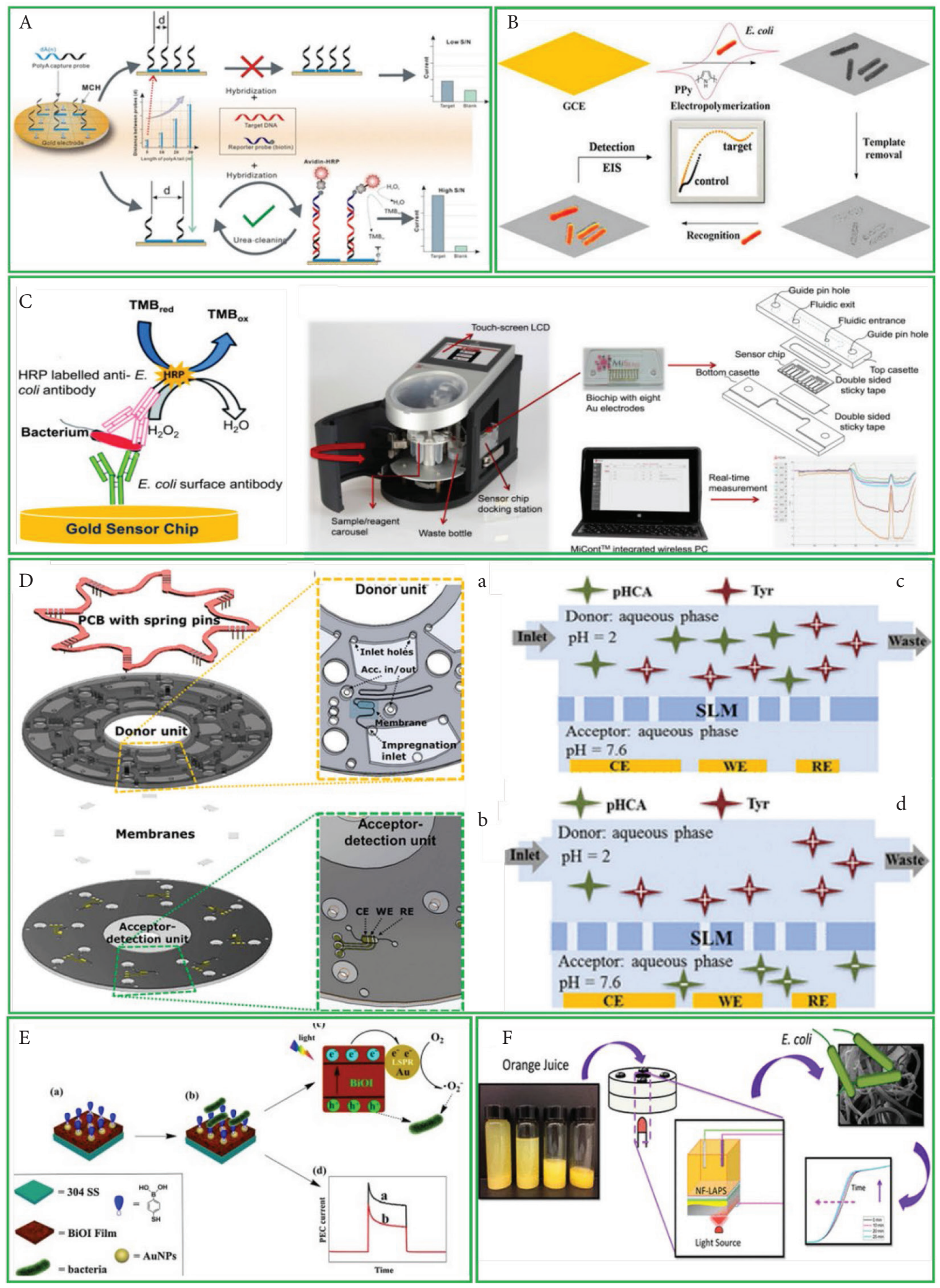

Figure 1 (A) Electrochemical DNA sensor based on the assembling strategy using a poly A capture probe [33]. (B) The construction of BIP film-based sensor involving three consecutive procedures: the BIP film preparation, bacterial recognition and impedimetric detection [34]. (C) Illustration of custom-designed MiSens biosensor integrating microfluidic system, biochip design and real-time amperometry [27]. (D) Inner diagram of the lab-on-adisc sensor with integrated supported liquid membrane (SLM) extraction and embedded electrodes for detection; a) Illustrative diagram of the donor unit and b) acceptor-detection unit; c) pHCA becomes neutral, while Tyr (existing basic amino group) is positively charged in the acceptor unit; d) During the extraction process, neutral pHCA diffuses to the SLM to the acceptor site, where it becomes negatively charged [28]. (E) Photoelectrochemical system for capture, detection, and inactivation of E. coli [36]. (F) LAPS sensor using a Si-based chip with pH sensitive hydrogel nanofibers [29]. 
sites situated in the surface of BIP film have high affinity for pathogens, which advances the mass transfer and the binding kinetics. There was a detection limit of E. coli O157:H7 concentration low to $10^{3} \mathrm{CFU} / \mathrm{mL}$, which was consistent with the antibody-based results. And the sensor has obtained ideal recoveries for analyzing real samples (drinking water, milk, and apple juice) artificially spiked with targets. This BIP-based sensing method provides a conceptual definition for other pathogens analysis.

To date, electrochemical microfluidics sensors incorporating sample pretreatment modules and detection modules have achieved fully automated or semi-automated detection of E. coli. For example, a fully automated microfluidic-based amperometry has applied for portable and on-site detection of E. coli in water sample [27]. The use of gold nanoparticles (AuNPs) conjugated antibody significantly enhanced the sensing performance (Figure 1C). The sensitivity of the device to E. coli was found to be $50 \mathrm{CFU} / \mathrm{mL}$ in water sample. The sensor could reuse the same sensing surface to test different bacteria concentrations. Furthermore, this study has excellent potential for the quantification of food pathogens and clinical sample analysis. Genetically modified E. coli expressing tyrosine (Tyr) ammonia-lyase could convert Tyr to hydroxycinnamic acid (pHCA). In order to realize efficient detection of pHCA in complex samples, there was a centrifugal fluidic platform consisting of supported liquid membrane extraction and SWV detection (Figure 1D) [28]. Although this method is beneficial for online monitoring of bacterial bioprocess, it can only test single sample in a small volume $(3 \mu \mathrm{L})$, which requires the modification of nanomaterials on the electrode to improve the sensitivity of the sensing system. Hence, a lab-on-a-disc platform integrated eight sample filtration and electrochemical detection for pHCA [35]. Due to the proximity of the redox potentials of the pHCA and the substrate (Tyr), the filtration device was used to screen pHCA from the culture medium. The platform could availably quantify the concentration of pHCA in the range from 0.125 to $2 \mathrm{mM}$. Moreover, the sensor is expected to achieve at-time monitoring the dynamic change of pHCA in the biological process.

Photoelectrochemical platforms have attracted extremely interest in sensing analysis owing to its low cost, rapid response, and high sensitivity. Researchers have integrated optical materials into sensors and devoted to improve sensing performance. There were photo-electricity conversion unit, visible light driven (VLD) photocatalytic antibacterial unit, AuNPs link unit and capture unit in a multifunctional photoelectrochemical system (Figure 1E) [36]. E. coli could be captured on the photoelectrode surface by the reversible binding between boronic acid group and peptidoglycan of the bacteria cell wall, which causes a decrease of photocurrent owing to the steric hindrance blocking the transfer of electron donor to photoelectrode surface. This technology has a profound impact on the application of VLD photocatalytic materialbased photoelectrochemical sensor. Besides, a portable device integrating hydrogel nanofibers with light addressable potentiometric sensor (LAPS) was developed in food safety application (Figure 1F) [29]. The sensitivity of the sensor toward E. coli in undiluted orange juice was found to be $10^{2} \mathrm{CFU} / \mathrm{mL}$. The designed nanofibers-LAPS has been a promising technology to ensure other fruit juices safety at different processes of production, distribution, and consumption.

\subsection{Electrochemical Sensors for Detection of Salmonella}

Genus Salmonella is an important member of the family enterobacteriaceae, which consists of Salmonella enterica (S. enterica) and Salmonella bongori [37]. In general, human infections resulting from 2500 Salmonella serovars are particularly in connection with contaminated foods typically pork, eggs, poultry, vegetables, and fresh fruits. Common symptoms, such as typhoid fever, paratyphoid fever and gastroenteritis, have drawn correlative researchers' attention to food safety problems caused by Salmonella [38].

Silva et al. [39] integrated polymer membrane solid layer enveloping AuNPs-antibody on miniaturized ion selective electrodes (i.e., pipette tip electrode) to fabricate an electrochemical immunosensor. When the antibody interacts with Salmonella typhimurium (S. typhi) to stable state, it blocks selective ions (non-redox activity) mass transfer to the bulk solution, resulting in electromotive force change in aqueous layer (Figure 2A). The designed sensor was used to directly analyze bacteria from commercial apple juice in complete analysis time, less than $1 \mathrm{~h}$. A lower detection limit of 6 cells/mL was obtained. Due to its low cost, label-free strategy and fast response, the sensor can be a good prototype device for responsing different pathogenic bacteria. In addition to the pipe tip electrode, LIG electrode has been successfully applied to the construction of $S$. typhi immunosensor due to its unique high electrical conductivity, chemical stability, low cost, and rapid synthesis under loose conditions [24]. The immunosensor was attained through laser inducing polyimide film to form porous graphene electrode in ambient conditions and antibody functionalization on LIG electrodes in turn (Figure 2B). LIG biosensor could detect live bacteria from chicken soup in a wide range of $25-10^{5} \mathrm{CFU} / \mathrm{mL}$ with a low detection limit of $13 \mathrm{CFU} / \mathrm{mL}$. The results demonstrated that the sensing method was a viable option for ensuring uncontaminated foods reach the consumer.

As we know, the combination of pure electrodes and biological receptors could hardly achieve the high sensitivity detection of Salmonella. Therefore, more researches have focused on functionalized nanomaterials, magnetic separation techniques, and amplification reactions [polymerase chain reaction (PCR); helicase-dependent amplification (HDA)] to design signal amplification strategies. Barreda-García et al. [40] fabricated a HDA-electrochemical genosensor to improve Salmonella analysis to the single copy level. The detectability of this sensor improved in two-fold of the real-time PCR. The other sensitive sensor was based on aptamer coated gold interdigitated microelectrode and nickel nanowire binding to antibody for Salmonella capture and separation, respectively (Figure 2C) [41]. The detection limit of $80 \mathrm{CFU} / \mathrm{mL}$ was obtained in the range from $10^{2}-10^{6}$ $\mathrm{CFU} / \mathrm{mL}$. Besides, Bu et al. [42] encapsulated ferrocenes into AMPs- $\mathrm{Cu}_{3}\left(\mathrm{PO}_{4}\right)_{2}$ nanocomposites as signal amplification probe. Antibody-coated magnetic beads were used to capture and concentrate the target cells. The result showed a low detection limit of $3 \mathrm{CFU} / \mathrm{mL}$ and a linear range from $10-10^{7} \mathrm{CFU} / \mathrm{mL}$.

Microfluidic technology integrating immune separation and enrichment of bacteria could implement simultaneous measurements of multiple analytes, which is expected to realize lab-ona-chip system for on-site analysis of Salmonella. The constructed 


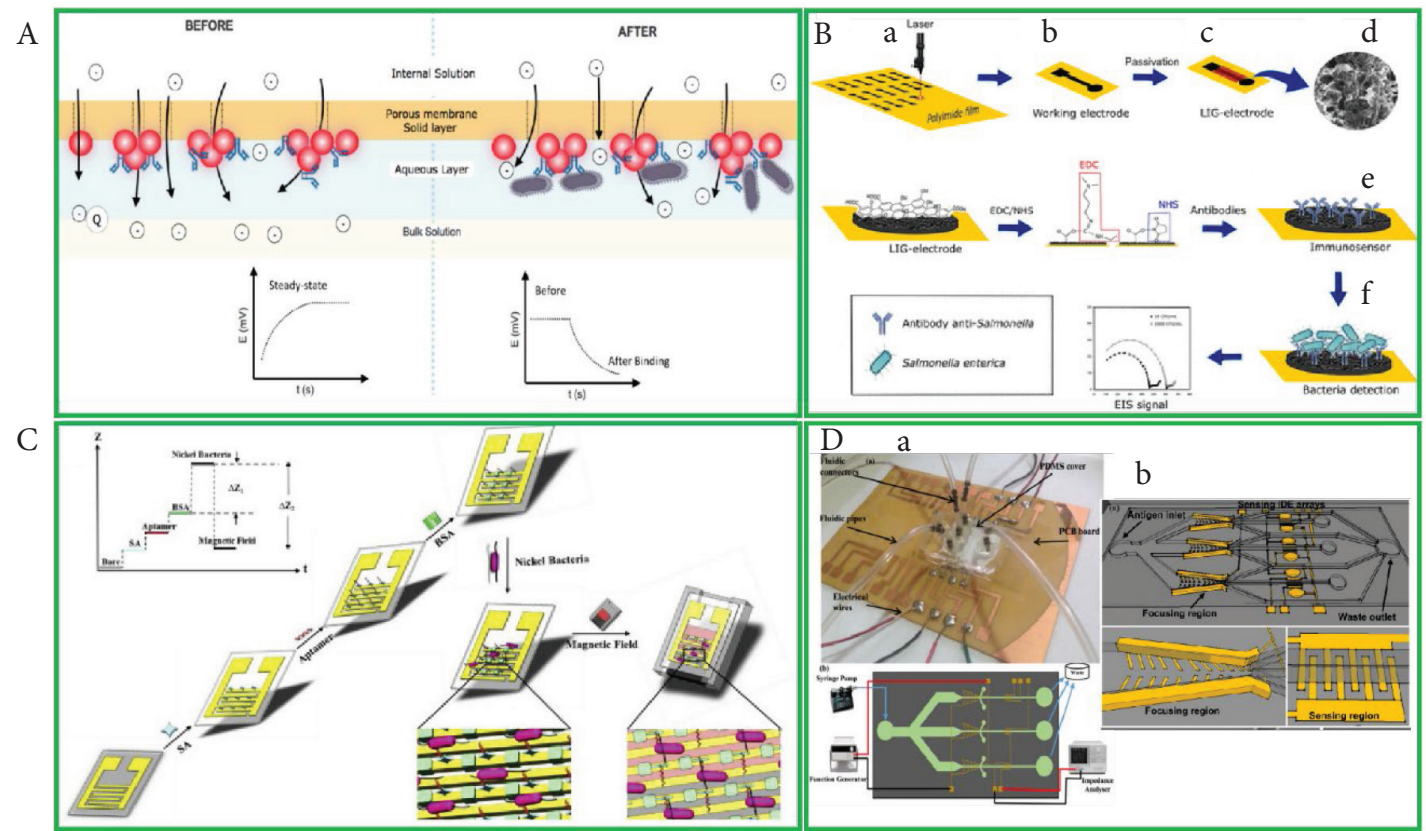

Figure 2 (A) Schematic of surface blocking effect detection mechanism on sensing interface [39]. (B) Fabrication, biofunctionalization, and sensing scheme of the LIG immunosensor [24]. (C) Electrochemical biosensor based on aptamer-bacteria-nickel nanowire complexes on interdigitated microelectrode [41]. (D) a) Completely fabricated bonded biosensor showing the fluidic connectors and tubes; b) Schematic images of impedance-based sensor, magnified view showing the focusing electrode, and magnified view of the detection electrodes [44].

hundreds of disposable microfluidic devices were feasible to achieve simultaneous measurement of eight samples with a low LOD of 7.7 cells $/ \mathrm{mL}$, in a linear range from 10-100 cells $/ \mathrm{mL}$ [43]. And other researchers used positive dielectrophoresis to concentrate the antigens for highly sensitive detection of three Salmonella serogroups with a LOD of 7 cells $/ \mathrm{mL}$ [44]. The sensing principle was the binding of antigen to antibody, leading to the impedance signal change (Figure 2D). This microfluidic sensor could differentiate live bacteria from the dead ones, which was applied in process control in slaughter processing plants.

\subsection{Electrochemical Sensors for Detection of Staphylococcus aureus}

S. aureus is a representative of gram-positive bacterium and is a common foodborne pathogenic microorganism [45]. Under appropriate conditions, it can produce enterotoxin and cause food poisoning with symptoms of nausea, vomiting, diarrhea, and dehydration. S. aureus is also the main culprit for furunculosis [8]. Moreover, mutations in the gene sequence of $S$. aureus could lead to the production of drug-resistant strains (methicillin-resistant S. aureus, MRSA), and further resistance against $\beta$-lactamases [46]. Therefore, timely prevention and sensitive detection technology is the most effective measurement to deal with the outbreak of S. aureus and drug-resistant strains.

Recently, quantitative analysis of $S$. aureus has focused on ultrasensitive detection and multifunctional sensing platform. Cai et al. [26] utilized strand displacement amplification and triplehelix molecular switch to determinate S. aureus. Guanine (G)-rich probe was anchored to the stem of molecule switch to form triplehelix DNA structure, which could improve sensitivity and prevent guanine tetramer formation. The strand shift amplification technique was used to release more single stranded DNA (ssDNA) that was completely complementary to the ring region of the molecular switch, resulting in the probe being exposed to the solution to form guanine tetramer. The guanine tetramer could bind to heme to form the electroactive complex (Figure 3A). This sensor provided a high sensitivity and a low detection limit of $8 \mathrm{CFU} / \mathrm{mL}$. And the sensor was applied for S. aureus detection in lake water, tap water and honey samples. Based on the unique charge properties of bacteriophages, Farooq et al. [47] orientated phages onto the electrode surface modified nanocomposites, highly porous bacterial cellulose (BC)/carboxylated multiwalled carbon nanotubes (c-MWCNTs). BC with highly porous and fibrous, offered a huge surface area for the impregnation of c-MWCNTs. Polyethyleneimine (PEI)-functionalized nanocomposites could identify the head of phages with negative electricity. The exposed tail was used to capture bacteria (Figure 3B). The DPV based biosensor could detect $3 \mathrm{CFU} / \mathrm{mL}$ and $5 \mathrm{CFU} / \mathrm{mL}$ of $S$. aureus in phosphate buffer saline and milk, respectively. And the biosensor provided a sensitive, specific, and accurate tool for early detection of $S$. aureus in food samples. Multifunctional analysis platform integrating simultaneous detection, elimination, and inactivation of pathogens was an efficient technology [48]. Vancomycin was specific to peptidoglycan on the bacteria cell wall to capture target cells. Silver ions released by silver nanoparticles (AgNPs) were able to kill bacteria (Figure 3C). The platform relied on the vancomycinfunctionalized $\mathrm{AgNPs} / \mathrm{ZnO}$ nanorod arrays can measure S. aureus with a LOD of $3.3 \times 10^{2} \mathrm{CFU} / \mathrm{mL}$. It has profound significance using multifunctional biosensor to implement pathogens analysis in water.

Besides, multi-signal probes (MSP) system for determination of mecA genes of MRSA has attracted our attention [46]. In MSP 
A

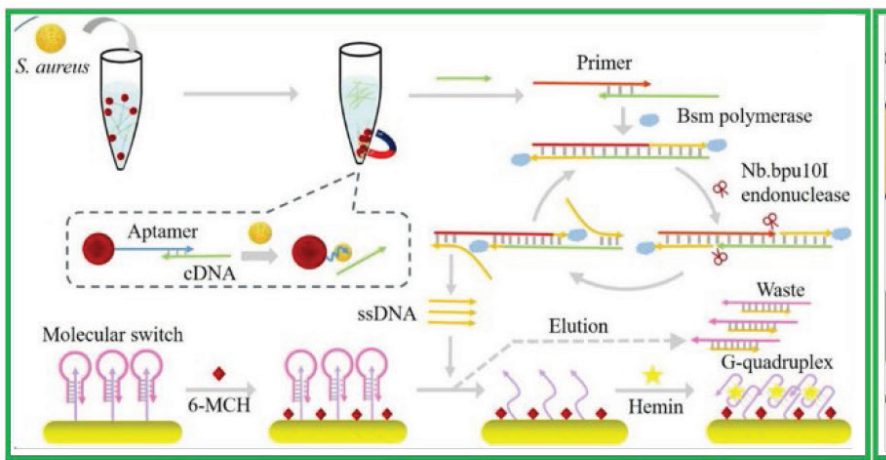

C

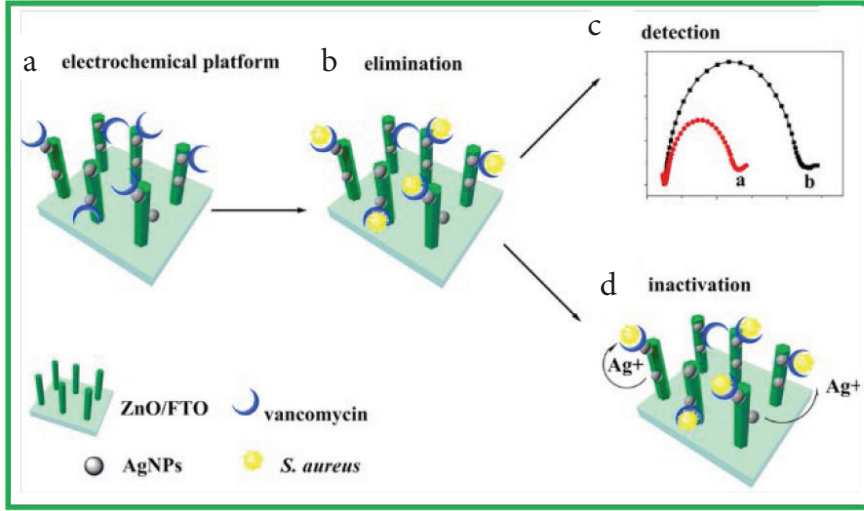

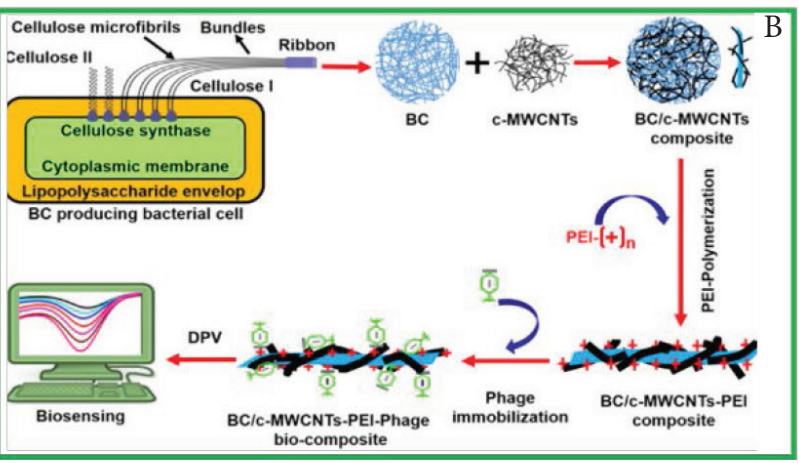

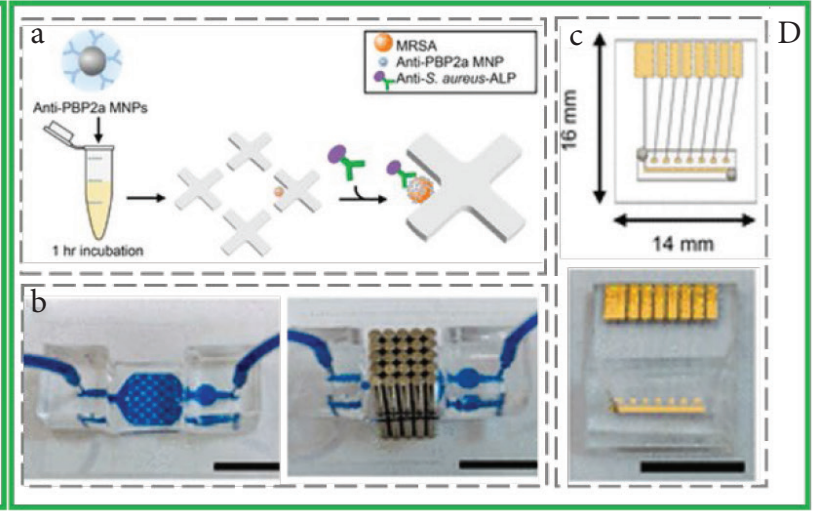

Figure 3 (A) Scheme of the electrochemical biosensor for S. aureus based on triple-helix molecular switch [26]. (B) Design process of ultrasensitive sensor: BC production, incorporation of c-MWCNTs into its matrix, its cationic modification with PEI, immobilization of phages in the PEI-modified BC fibers, and DPV detection [47]. (C) Multifunctional electrochemical platform for simultaneous detection, elimination, and inactivation of S. aureus [48]. (D) a) Schematic representation of the microfluidic platform including bacterial capture unit and electrochemical detection unit (b, c) [30].

system, the use of seven biotin-labelled signal probes remarkably improved the approachability of target sequence embedded in complex DNA structures. The MSP system could improve stability of the entire system by optimizing the density of capture probes. In comparison with other gene sensors [49,50], this sensor had a lower LOD, $57 \mathrm{fM}$ mecA genes. However, it is only prospect for instrument to achieve microminiaturization and on-site monitoring of real sample. Subsequently, Nemr et al. [30] integrated magnetic capture unit and electrochemical detection unit in a microfluidic platform (Figure 3D). Due to penicillin-binding protein 2a (PBP2a) leading to methicillin resistance, anti-PBP2a antibodies functionalized magnetic nanoparticles was used to specifically capture MRSA. Then, alkaline phosphatase (ALP)-functionalized anti-S. aureus antibodies could recognize magnetic MRSA. This technique has been successfully used in clinical diagnosis and has great potentiality to accommodate different bacteria.

\subsection{Electrochemical Sensors for Detection of Listeria monocytogenes}

Listeria monocytogenes, opportunistic foodborne pathogens, generally exist in ready-to-eat foods, such as seafood products, milk products, and heat-treated meat products [51]. Elderly, pregnant women, neonates and immunocompromised population are at higher risk in infecting the disease. Lm could be capable of triggering septicemia, meningitis, abortion, stillbirth, and meningoencephalitis endangering human health [52].
Molecular-based electrochemical biosensors mainly consist of molecular amplification process and electrochemical detection of specific DNA or ribonucleic acid (RNA) sequences in pathogens [52]. Recently, an integrated strategy based on double-stranded DNA PCR amplification products and electrochemical immunoluminescence (ECL) was proposed [53]. An inexpensive and disposable paper-based bipolar electrode was demonstrated to Lm DNA analysis (Figure 4A). The maximum signal of the sensor was observed within $10 \mathrm{~s}$. The sensor had a detection limit of 10 copies $/ \mu \mathrm{L}$ of genomic DNA. Moreover, the technology demonstrated advance in biological, clinical, and environmental applications. Among isothermal molecular amplification techniques, the sensitivities of LAMP and recombinase polymerase amplification (RPA) assays were higher than PCR [54,55]. For example, aptamers magnetic capture (AMC)-LAMP could achieve the LOD of $5 \mathrm{CFU} / \mathrm{mL}$. The key advantage of the designed AMCLAMP was the exemption of sophisticated experiment devices and pre-analytical culture enrichment procedure [54]. Another example, RPA-lateral flow dipstick (LFD) technology was regarded as a solution for POC testing. Although the LFD for pathogens analysis just requires simple equipment, it is limited to researching lots of actual samples [55]. In summary, molecular amplification technology could be used to design electrochemical sensor, which is undoubtedly conducive to the realization of ultrasensitive and POC analysis.

Recently, there was an electrochemical biosensor able to perform multiplexed detection of $L m$ using peptide as recognition receptor 


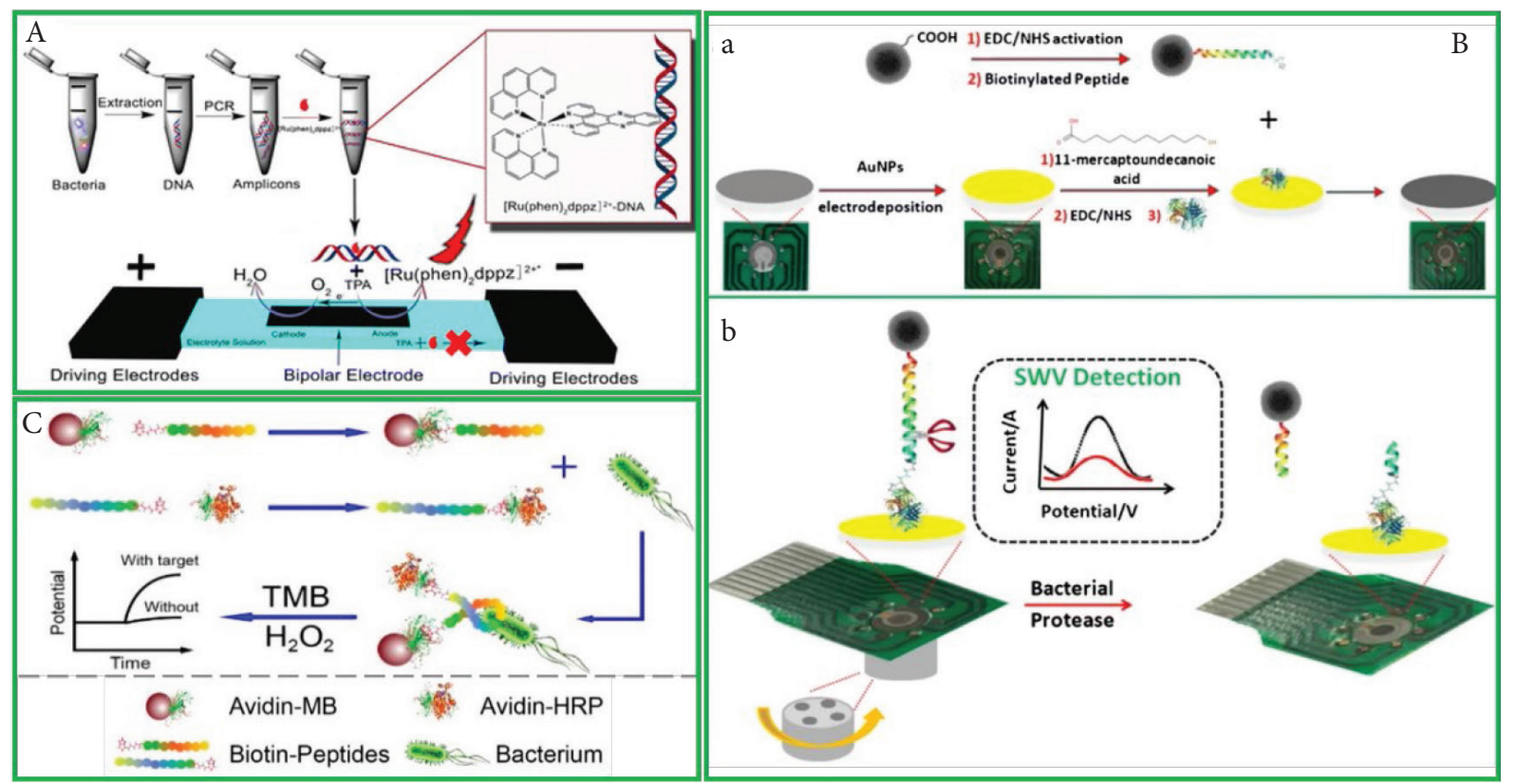

Figure 4 (A) Analysis principle of the bipolar electrode-ECL molecular switch system [53]. (B) Scheme of the multiplexed array biosensor. (a) The fabrication process of peptide-magnetic bead/AuNPs/SPCE. (b) Electrochemical detection mechanism: the specific cleavage of peptides through bacterial proteases causing the changes in electrical signals on the sensor surface [56]. (C) Scheme of the potentiometric sandwich assay based on short antimicrobial peptide pairs [57].

and proteases enzyme produced from bacteria as marker [56]. Each protease enzyme had the capability to break a peptide bond at specific site causing a dissociation of the magnetic nanoparticles from the electrode surface which can be detected by SWV (Figure 4B). This biosensing system enabled to achieve fast and multiplexed analysis for $L m$, with a detection limit of $9 \mathrm{CFU} / \mathrm{mL}$. Compared to multiple peptides, short peptides had high specificity for the target. Moreover, the short peptides with less positive charges could also reduce the adsorption of interferences species in real samples (such as other bacteria and negatively charged species). And thus, Lv et al. [57] used short peptide pairs obtained from splitting the original peptides to design potentiometric biosensors for $\mathrm{Lm}$ (Figure $4 \mathrm{C}$ ). Similarly, $\mathrm{Lm}$ could be detected in a linear range of $10^{2}$ to $10^{6} \mathrm{CFU} / \mathrm{mL}$, with a LOD of $10 \mathrm{CFU} / \mathrm{mL}$. This approach broadened the applications of peptides-based pathogen biosensors in the field of food safety.

Polyclonal antibody (PAb) may identify multiple epitopes on any antigen, while a monoclonal antibody (MAb) may detect only one epitope on any antigen [58]. The general principles are as follows: (1) magnetic nanomaterials based on PAb specifically capture target bacteria and isolate them; (2) MAb-based AuNPs carry catalytic materials, such as urease, to catalyze the reaction of electroactive material. A low-cost screen-printed electrode was used to detect $L m$ in the range of $1.9 \times 10^{3}-1.9 \times 10^{6} \mathrm{CFU} / \mathrm{mL}$. The designed sensor was suitable for in-field analysis [59]. Additionally, Chiriacò et al. [60] designed a miniaturized biochip integrating an array of interdigitated antibodies-functionalized electrodes for Lm analysis in clinical and on-site detection. The biochip achieved high-throughput and high sensitivity with a LOD of $5.5 \mathrm{CFU} / \mathrm{mL}$. However, it requires data processing skills and simple samples. Therefore, future work should focus on addressing these challenges and obstacles.

\subsection{Electrochemical Sensors for Detection of Other Bacteria}

Vibrio parahaemolyticus (Vp), one gram-negative halophilic acrogenous bacterium, was found in zooplankton, coastal fish, and shellfish. Once $V p$-contaminated seafood absorbed via the body, it would cause severe diarrheal disease gastroenteritis, acute gastroenteritis. The presence of $V p$ would lead to the outbreak of foodborne diseases and endanger the safety of human life. Teng et al. [61] developed an antibody-aptamer based electrochemical sensor for ultrasensitive detection of $\mathrm{Vp}$. This protocol provided a versatile platform and detected the lower concentration of $2 \mathrm{CFU} / \mathrm{mL}$ in spiked fish samples. But the fabrication procedures of sensor still need further simplification. Fortunately, a POC device integrating a diminutive potentiostat and unmodified screenprinted graphene electrodes (SPGE) can effectively detect LAMP amplicons [62]. In addition, ECL immunoassay with high sensitivity has been employed for $V p$ detection with a detection limit of 5 CFU/g for seafood [63]. However, ECL response is especially sensitive to nonspecific substance, leading to relatively low reliability. Therefore, researchers provided a Faraday cage-type immunosensor to achieve ECL and anodic stripping voltammetry dual-modal detection, which could improve the reliability of sensors [64]. The Faraday cage-type structure could enhance signal effects. The results showed a detection limit of $33 \mathrm{CFU} / \mathrm{mL}$.

Campylobacter jejuni, Campylobacter hepaticus, and Campylobacter coli belong to Campylobacter species, all playing their part in foodborne diseases associated with human. Lately, researchers explored the effects of single leg skin samples and pooled neck skin samples from on the detection of Campylobacter contaminated chicken. The results showed that, by changing from single leg skin to the pooled neck skin, the estimated sensitivity and prevalence could 
both increase by $\sim 1.6$ times [65]. A multiplex PCR was designed to simultaneously identify the presence of different Campylobacter species in chicken samples. The assay may be a new and viable diagnostic tool for evaluating bacteria contaminated meat product [66]. However, there are few papers based on electrochemical biosensor to detect Campylobacter.

Cholera is an acute diarrhoeal infectious disease caused by the ingestion of food or water contaminated with Vibrio cholerae. To satisfy POC diagnosis such as higher levels of sensitivity and specificity, simplification, portability and low cost, Valera et al. [67] reported an on-chip biosensing platform for the detection of cholera toxin subunit B. Gold dendrites functionalized via poly(2-cyanoethyl)pyrrole (PCEPy) was used as working electrode and could allow for a higher level of detection sensitivity. This sensor was more sensitive (detection limit of $1 \mathrm{ng} / \mathrm{mL}$ ) than detection using a simple planar gold electrode (detection limit of $100 \mathrm{ng} / \mathrm{mL}$ ). The on-chip device represents a promising avenue for POC disease diagnosis in resource limited areas. Further work is toward realization as an on-chip diagnostic device integrating microfluidic technology.

Besides, researchers designed an aptasensor for low-cost and highly specific response of Shigella dysenteriae in dairy products [68]. Aptamers were assembled on AuNPs modified electrode. Moreover, the fabricated biosensor had an admirable sensitivity with a LOD of $1 \mathrm{CFU} / \mathrm{mL}$. Due to its good performance, it could be a practical tool in food or clinical quality control. Also, Yuan et al. [69] designed a cascade signal amplification based on reverse transcription (RT)-PCR triggering G-quadruplex DNAzyme catalyzed reaction to determine Cronobacter sakazakii. Only tDNA could initiate RT-PCR reaction and the G-quadruplex binding with hemin assembled an artificial DNAzyme to catalyze the oxidation of $3,3^{\prime}, 5,5^{\prime}$-tetramethylbenzidine by $\mathrm{H}_{2} \mathrm{O}_{2}$. The electrochemical sensor could detect Cronobacter sakazakii with a detection limit of $5.01 \times 10^{2} \mathrm{CFU} / \mathrm{mL}$. Due to the advantages of high sensitivity, low cost and simple manipulation, this approach provides the option of potential application in other pathogen detection.

\section{CRITICAL DISCUSSIONS}

In the last decade, most of the work was devoted to synthesizing new functional materials and designing novel sensing principle that greatly enhance sensitivity, selectivity, overpotential reduction and stability. Though there is considerable improvement in the applications of electrochemical sensors for foodborne bacteria detection, there are few limitations, which hinder these applications for the next level. The specific limitations are as follows.

Nucleic acids and aptamers are used as bioreceptor elements and retain its long last activity, which is a critical issue in front of the researchers. The sustainability of sensing materials (such as nanomaterials) in sensor applications, has been insufficiently investigated. The fabrication process and toxicity of functional materials change according to the physical properties of the material type [100]. Therefore, improving the stability of bioreceptor elements and functional materials, and then developing the service life of sensors are the critical issue worthy of investigation by researchers.

Highly sensitive detection of foodborne bacteria is still a goal pursued by researchers. Small volume samples, such as skin, intestines, intestinal mucosa and other special occasions of the human body
[101,102], could be detected using highly sensitive devices. It is feasible to dilute the actual sample (small volume) and then test it. And the sensor with such lower detection limit is conducive to rapidly screen suspected patients. Of course, high sensitivity may mean poor accuracy, so how to balance the sensitivity and accuracy of the sensing method needs to be considered by researchers in the relevant field. Besides, the nonspecific adsorption of the sensors in the food complex matrix could lead to poor accuracy of detection results. Thus, it is inevitable to carry on tedious pretreatment to the actual sample. Currently, very few sensors have attained commercial success, apart from electrochemical glucose sensors and lateral flow pregnancy tests $[100,103]$. Electrochemical bacteria sensor integrated into affordable cost, miniaturization, portability, high accuracy and easy operability still remain challenges.

\section{CONCLUSION AND FUTURE PROSPECTS}

Foodborne pathogenic bacteria continue to hold their viability and express their poisonousness. It is extremely significant for timely prevention, specific identification, sensitive and rapid response (or online monitoring) of pathogens. Electrochemical sensor is a sustainable and indispensable diagnostic tool for pathogens analysis. As an ideal electrochemistry sensor, it needs to meet the following requirements: (1) the interface design of the sensor is preferably to have the advantages of simple operation, low cost, high specificity, and large surface area; (2) the whole system satisfies miniaturization, commercialization, functional integration, full automatization, and wide application. Nowadays, only a few sensors have satisfied this criterion, but most sensors are still facing challenges.

Selectivity is one of the key factors to determine the performance of sensors. At present, AMPs as low-cost biorecognition elements obtained from natural substances (such as plants and microorganisms) are attractive candidates. In addition, short peptides replacing long chain peptides could efficiently improve the specificity of devices. However, current methods of interface design have limitations to the stability and repeatability of analytical results. We can combine contactless $3 \mathrm{D}$ printing technology to the sensing interface to improve analytical accuracy, reproducibility, and service life of the sensor. Also, the integration of artificial intelligence will greatly enrich the data module. Significantly, high sensitivity has always been the most prominent characteristic of electrochemical sensing over other analytical methods. Micro-machining technology (like DNA walking machine) combined with new active nanomaterials and optical materials could improve the sensitivity of the system.

It is noted that only several sensors have been commercialized and evolved conceptual approaches into practical applications. Miniaturized equipment for on-site analysis is a luxury for the public. During the whole analysis process, the culture of bacterial strain often requires controlled temperature and specific environment, which is time-consuming in spite of being sensitive and accurate. Of course, most pre-treatment process of real samples cannot detach from the standard laboratory. Future researchers could combine artificial intelligence technology to solve the confusion of practical application. At last, we hope to provide a bridge to connect the gap between food science and electrochemical sensors. 


\section{CONFLICTS OF INTEREST}

The authors declare they have no conflicts of interest.

\section{AUTHORS' CONTRIBUTION}

YW contributed in investigation, design, review, writing and revision. XM, XQ and PY contributed in investigation and discussion. QS, MZ and TY contributed in conceptualization, supervision, revision, editing and critical review.

\section{ACKNOWLEDGMENTS}

This work was supported by National Key R\&D Program of China (2019YFC1606703) and the Natural Science Foundation of Shaanxi Province in China (2020JM-429).

\section{REFERENCES}

[1] Vanegas DC, Gomes CL, Cavallaro ND, Giraldo-Escobar D, McLamore ES. Emerging biorecognition and transduction schemes for rapid detection of pathogenic bacteria in food. Compr Rev Food Sci Food Saf 2017;16:1188-205.

[2] Krivonogova A, Isaeva A, Loretts O, Chentsova A. Composition and antibiotic susceptibility of opportunistic pathogenic microflora in poultry farms aimed at egg or meat farming. Advances in Intelligent System Research, Proceedings of the International Scientific and Practical Conference "Digital agriculture - development Strategy" (ISPC). Paris: Atlantis Press; 2019, pp. 542-5.

[3] Hameed S, Xie L, Ying Y. Conventional and emerging detection techniques for pathogenic bacteria in food science: a review. Trends Food Sci Technol 2018;81:61-73.

[4] Amiri M, Bezaatpour A, Jafari H, Boukherroub R, Szunerits S. Electrochemical methodologies for the detection of pathogens. ACS Sens 2018;3:1069-86.

[5] Yang L, Bashir R. Electrical/electrochemical impedance for rapid detection of foodborne pathogenic bacteria. Biotechnol Adv 2008;26:135-50.

[6] Pashazadeh P, Mokhtarzadeh A, Hasanzadeh M, Hejazi M, Hashemi M, de la Guardia M. Nano-materials for use in sensing of salmonella infections: recent advances. Biosens Bioelectron 2017;87:1050-64.

[7] Wu QP, Fan HY, Zhang JM. Review on immune and new molecular detective techniques for foodborne bacterial pathogens. Food Sci 2005;26:269-73.

[8] Abdalhai MH, Fernandes AM, Bashari M, Ji J, He Q, Sun X. Rapid and sensitive detection of foodborne pathogenic bacteria (Staphylococcus aureus) using an electrochemical DNA genomic biosensor and its application in fresh beef. J Agric Food Chem 2014;62:12659-67.

[9] Inbaraj BS, Chen BH. Nanomaterial-based sensors for detection of foodborne bacterial pathogens and toxins as well as pork adulteration in meat products. J Food Drug Anal 2016;24: $15-28$.

[10] Xu M, Wang R, Li Y. Electrochemical biosensors for rapid detection of Escherichia coli O157:H7. Talanta 2017;162:511-22.
[11] Abdalhai MH, Fernandes AM, Xia X, Musa A, Ji J, Sun X. Electrochemical genosensor to detect pathogenic bacteria (Escherichia coli O157:H7) as applied in real food samples (fresh beef) to improve food safety and quality control. J Agric Food Chem 2015;63:5017-25.

[12] Lough F, Perry JD, Stanforth SP, Dean JR. Detection of exogenous VOCs as a novel in vitro diagnostic technique for the detection of pathogenic bacteria. TrAC Trends Anal Chem 2017;87:71-81.

[13] Xu L, Lu Z, Cao L, Pang H, Zhang Q, Fu Y, et al. In-field detection of multiple pathogenic bacteria in food products using a portable fluorescent biosensing system. Food Control 2017;75:21-8.

[14] Hasan MR, Pulingam T, Appaturi JN, Zifruddin AN, Teh SJ, Lim TW, et al. Carbon nanotube-based aptasensor for sensitive electrochemical detection of whole-cell Salmonella. Anal Biochem 2018;554:34-43.

[15] Gao G, Wang D, Brocenschi R, Zhi J, Mirkin MV. Toward the detection and identification of single bacteria by electrochemical collision technique. Anal Chem 2018;90:12123-30.

[16] Li T, Zhu F, Guo W, Gu H, Zhao J, Yan M, et al. Selective capture and rapid identification of $\mathrm{E}$. coli $\mathrm{O} 157: \mathrm{H7}$ by carbon nanotube multilayer biosensors and microfluidic chip-based LAMP. RSC Adv 2017;7:30446-52.

[17] Yamazaki A, Honda M, Kobayashi N, Ishizaki N, Asakura H, Sugita-Konishi Y. The sensitivity of commercial kits in detecting the genes of pathogenic bacteria in venison. J Vet Med Sci 2018; 80:706-9.

[18] Bu SJ, Wang KY, Ju CJ, Wang CY, Li ZY, Hao Z, et al. Point-of-care assay to detect foodborne pathogenic bacteria using a low-cost disposable medical infusion extension line as readout and $\mathrm{MnO}_{2}$ nanoflowers. Food Control 2019;98:399-404.

[19] Guedes TJ, Santos WT. Fast and simple electrochemical analysis kit for quality control of narrow therapeutic index drugs. Electroanalysis 2018;30:1740-9.

[20] Punter-Villagrasa J, Colomer-Farrarons J, del Campo FJ, Miribel-Català P. Introduction to Electrochemical Point-ofCare Devices. In: Amperometric and Impedance Monitoring Systems for Biomedical Applications. Bioanalysis (Advanced Materials, Methods, and Devices). Springer, Cham, 2017. pp. $1-26$.

[21] Formisano N, Bhalla N, Heeran M, Martinez JR, Sarkar A, Laabei $\mathrm{M}$, et al. Inexpensive and fast pathogenic bacteria screening using field-effect transistors. Biosens Bioelectron 2016;85:103-9.

[22] De Rycke E, Stove C, Dubruel P, De Saeger S, Beloglazova N. Recent developments in electrochemical detection of illicit drugs in diverse matrices. Biosen Bioelectron 2020;169:112579.

[23] Kaur H, Shorie M, Sharma M, Ganguli AK, Sabherwal P. Bridged Rebar Graphene functionalized aptasensor for pathogenic E. coli O78:K80:H11 detection. Biosens Bioelectron 2017;98:486-93.

[24] Soares RRA, Hjort RG, Pola CC, Parate K, Reis EL, Soares NFF, et al. Laser-induced graphene electrochemical immunosensors for rapid and label-free monitoring of Salmonella enterica in chicken broth. ACS Sens 2020;5:1900-11.

[25] Yao L, Wang L, Huang F, Cai G, Xi X, Lin J. A microfluidic impedance biosensor based on immunomagnetic separation and urease catalysis for continuous-flow detection of E. coli O157:H7. Sensors Actuators B Chem 2018;259:1013-21.

[26] Cai RF, Zhang ZW, Chen HH, Tian YP, Zhou ND. A versatile signal-on electrochemical biosensor for Staphylococcus aureus based on triple-helix molecular switch. Sensors Actuators B Chem 2021;326:128842. 
[27] Altintas Z, Akgun M, Kokturk G, Uludag Y. A fully automated microfluidic-based electrochemical sensor for real-time bacteria detection. Biosens Bioelectron 2018;100:541-8.

[28] Andreasen SZ, Sanger K, Jendresen CB, Nielsen AT, Emnéus J, Boisen A, et al. Extraction, enrichment, and in situ electrochemical detection on lab-on-a-disc: monitoring the production of a bacterial secondary metabolite. ACS Sens 2019;4:398-405.

[29] Shaibani PM, Etayash H, Jiang K, Sohrabi A, Hassanpourfard M, Naicker S, et al. Portable nanofiber-light addressable potentiometric sensor for rapid Escherichia coli detection in orange juice. ACS Sens 2018;3:815-22.

[30] Nemr CR, Smith SJ, Liu W, Mepham AH, Mohamadi RM, Labib M, et al. Nanoparticle-mediated capture and electrochemical detection of methicillin-resistant Staphylococcus aureus. Anal Chem 2019;91:2847-53.

[31] Kaper JB, Nataro JP, Mobley HLT. Pathogenic Escherichia coli. Nat Rev Microbiol 2004;2:123-40.

[32] Gomes TAT, EliasWP, Scaletsky ICA, Guth BEC, Rodrigues JF, Piazza RMF, et al. Diarrheagenic Escherichia coli. Braz J Microbiol 2016;47:3-30.

[33] Li L, Wang L, Xu Q, Xu L, Liang W, Li Y, et al. Bacterial analysis using an electrochemical DNA biosensor with poly-adeninemediated DNA self-assembly. ACS Appl Mater Interfaces 2018; 10:6895-903.

[34] Wu J, Wang R, Lu Y, Jia M, Yan J, Bian X. Facile preparation of a bacteria imprinted artificial receptor for highly selective bacterial recognition and label-free impedimetric detection. Anal Chem 2019;91:1027-33.

[35] Sanger K, Zór K, Jendresen CB, Heiskanen A, Amato L, Nielsen AT, et al. Lab-on-a-disc platform for screening of genetically modified E. coli cells via cell-free electrochemical detection of p-Coumaric acid. Sensors Actuators B Chem 2017;253:999-1005.

[36] Yang Z, Wang Y, Zhang D. An integrated multifunctional photoelectrochemical platform for simultaneous capture, detection, and inactivation of pathogenic bacteria. Sensors Actuators B Chem 2018;274:228-34.

[37] Baniga Z, Mdegela RH, Lisa B, Kusiluka LJM, Dalsgaard A. Prevalence and characterisation of Salmonella Waycross and Salmonella enterica subsp. salamae in Nile perch (Lates niloticus) of Lake Victoria, Tanzania. Food Control 2019;100:28-34.

[38] Melo AMA, Alexandre DL, Furtado RF, Borges MF, Figueiredo EAT, Biswas A, et al. Electrochemical immunosensors for Salmonella detection in food. Appl Microbiol Biotechnol 2016;100:5301-12.

[39] Silva NFD, Magalhães JMCS, Barroso MF, Oliva-Teles T, Freire C, Delerue-Matos C. In situ formation of gold nanoparticles in polymer inclusion membrane: application as platform in a labelfree potentiometric immunosensor for Salmonella typhimurium detection. Talanta 2019;194:134-42.

[40] Barreda-García S, Miranda-Castro R, de-los-Santos-Álvarez N, Lobo-Castañón MJ. Sequence-specific electrochemical detection of enzymatic amplification products of Salmonella genome on ITO electrodes improves pathogen detection to the single copy level. Sensors Actuators B Chem 2018;268:438-45.

[41] Wang L, Huo X, Qia W, Xia Z, Li Y, Lin J. Rapid and sensitive detection of Salmonella typhimurium using nickel nanowire bridge for electrochemical impedance amplification. Talanta 2020;211:120715.
[42] Bu SJ, Wang KY, Liu X, Ma L, Wei HG, Zhang WG, et al. Ferrocene-functionalized nanocomposites as signal amplification probes for electrochemical immunoassay of Salmonella typhimurium. Microchim Acta 2020;187:600.

[43] de Oliveira TR, Martucci DH, Faria RC. Simple disposable microfluidic device for Salmonella typhimurium detection by magnetoimmunoassay. Sensors Actuators B Chem 2018;255:684-91.

[44] Jasim I, Shen Z, Mlaji Z, Yuksek NS, Abdullah A, Liu J, et al. An impedance biosensor for simultaneous detection of low concentration of Salmonella serogroups in poultry and fresh produce samples. Biosens Bioelectron 2019;126:292-300.

[45] Hidayatulail BF, Yasin M, Astuti SD. Photodynamic inactivation for pathogenic bacteria: adding chlorophyll and oxygen. Proceedings of the 1st International Conference Postgraduate School Universitas Airlangga: "Implementation of Climate Change Agreement to Meet Sustainable Development Goals" (ICPSUAS 2017). Advances in Social Science, Education and Humanities Research. Paris: Atlantis Press; 2017, pp. 277-80.

[46] Xu L, Liang W, Wen Y, Wang L, Yang X, Ren S, et al. An ultrasensitive electrochemical biosensor for the detection of mecA gene in methicillin-resistant Staphylococcus aureus. Biosens Bioelectron 2018;99:424-30.

[47] Farooq U, Ullah MW, Yang Q, Aziz A, Xu J, Zhou L, et al. Highdensity phage particles immobilization in surface-modified bacterial cellulose for ultra-sensitive and selective electrochemical detection of Staphylococcus aureus. Biosens Bioelectron 2020;157: 112163.

[48] Yang Z, Wang Y, Zhang D. A novel multifunctional electrochemical platform for simultaneous detection, elimination, and inactivation of pathogenic bacteria based on the vancomycinfunctionalised $\mathrm{AgNPs} / 3 \mathrm{D}-\mathrm{ZnO}$ nanorod arrays. Biosens Bioelectron 2017;98:248-53.

[49] Liu M, Xiang H, Hua E, Wang L, Jing X, Cao X, et al. Ultrasensitive electrochemical biosensor for the detection of the mecA gene sequence in methicillin resistant strains of Staphylococcus aureus employing gold nanoparticles. Anal Lett 2014;47:579-91.

[50] Watanabe K, Kuwata N, Sakamoto H, Amano Y, Satomura T, Suye S. A smart DNA sensing system for detecting methicillinresistant Staphylococcus aureus using modified nanoparticle probes. Biosens Bioelectron 2015;67:419-23.

[51] Vizzini P, Braidot M, Vidic J, Manzano M. Electrochemical and optical biosensors for the detection of Campylobacter and Listeria: an update look. Micromachines 2019;10:500.

[52] Liu A, Shen L, Zeng Z, Sun M, Liu Y, Liu S, et al. A minireview of the methods for Listeria monocytogenes detection. Food Anal Methods 2018;11:215-23.

[53] Liu H, Zhou X, Liu W, Yang X, Xing D. Paper-based bipolar electrode electrochemiluminescence switch for label-free and sensitive genetic detection of pathogenic bacteria. Anal Chem 2016; 88:10191-7.

[54] Feng J, Dai Z, Tian X, Jiang X. Detection of Listeria monocytogenes based on combined aptamers magnetic capture and loop-mediated isothermal amplification. Food Control 2018; 85:443-52.

[55] Gao W, Huang H, Zhang Y, Zhu P, Yan X, Fan J, et al. Recombinase polymerase amplification-based assay for rapid detection of Listeria monocytogenes in food samples. Food Anal Methods 2017;10:1972-81. 
[56] Eissa S, Zourob M. Ultrasensitive peptide-based multiplexed electrochemical biosensor for the simultaneous detection of Listeria monocytogenes and Staphylococcus aureus. Microchim Acta 2020;187:486.

[57] Lv E, Ding J, Qin W. Potentiometric detection of Listeria monocytogenes via a short antimicrobial peptide pair-based sandwich assay. Anal Chem 2018;90:13600-6.

[58] Välimaa AL, Tilsala-Timisjärvi A, Virtanen E. Rapid detection and identification methods for Listeria monocytogenes in the food chain - a review. Food Control 2015;55:103-14.

[59] Wang D, Chen Q, Huo H, Bai S, Cai G, Lai W, et al. Efficient separation and quantitative detection of Listeria monocytogenes based on screen-printed interdigitated electrode, urease and magnetic nanoparticles. Food Control 2017;73:555-61.

[60] Chiriacò MS, Parlangeli I, Sirsi F, Poltronieri P, Primiceri E. Impedance sensing platform for detection of the food pathogen Listeria monocytogenes. Electronics 2018;7:347.

[61] Teng J, Ye Y, Yao L, Yan C, Cheng K, Xue F, et al. Rolling circle amplification based amperometric aptamer/immuno hybrid biosensor for ultrasensitive detection of Vibrio parahaemolyticus. Microchim Acta 2017;184:3477-85.

[62] Kampeera J, Pasakon P, Karuwan C, Arunrut N, Sappat A, Sirithammajak S, et al. Point-of-care rapid detection of Vibrio parahaemolyticus in seafood using loop-mediated isothermal amplification and graphene-based screen-printed electrochemical sensor. Biosens Bioelectron 2019;132:271-8.

[63] Sha Y, Zhang X, Li W, Wu W, Wang S, Guo Z, et al. A label-free multi-functionalized graphene oxide based electrochemiluminscence immunosensor for ultrasensitive and rapid detection of Vibrio parahaemolyticus in seawater and seafood. Talanta 2016;147:220-5.

[64] Wang T, Song X, Lin H, Hao T, Hu Y, Wang S, et al. A Faraday cage-type immunosensor for dual-modal detection of Vibrio parahaemolyticus by electrochemiluminescence and anodic stripping voltammetry. Anal Chim Acta 2019;1062:124-30.

[65] Ellis-Iversen J, Gantzhorn MR, Borck Høg B, Foddai A, Nauta M. The ability to detect campylobacter presence and concentration using different chicken carcass samples. Food Control 2020;115: 107294.

[66] Van TTH, Anwar A, Scott PC, Moore RJ. Rapid and specific methods to differentiate foodborne pathogens, Campylobacter jejuni, Campylobacter coli, and the new species causing spotty liver disease in chickens, Campylobacter hepaticus. Foodborne Pathog Dis 2018;15:526-30.

[67] Valera AE, Nesbitt NT, Archibald MM, Naughton MJ, Chiles TC. On-chip electrochemical detection of cholera using a polypyrrole-functionalized dendritic gold sensor. ACS Sens 2019;4:654-9.

[68] Zarei SS, Soleimanian-Zad S, Ensafi AA. An impedimetric aptasensor for Shigella dysenteriae using a gold nanoparticlemodified glassy carbon electrode. Microchim Acta 2018;185:538.

[69] Yuan Y, Wu X, Liu Z, Ning Q, Fu L, Wu S. A signal cascade amplification strategy based on RT-PCR triggering of G-quadruplex DNAzyme for a novel electrochemical detection of viable Cronobacter sakazakii. Analyst 2020;145:4477-83.

[70] Helali S, Sawelem Eid Alatawi A, Abdelghani A. Pathogenic Escherichia coli biosensor detection on chicken food samples. J Food Saf 2018;38:e12510.

[71] Wilson D, Materón EM, Ibáñez-Redín G, Faria RC, Correa DS, Oliveira ON. Electrical detection of pathogenic bacteria in food samples using information visualization methods with a sensor based on magnetic nanoparticles functionalized with antimicrobial peptides. Talanta 2019;194:611-18.

[72] Wen Y, Wang L, Xu L, Li L, Ren S, Cao C, et al. Electrochemical detection of PCR amplicons of Escherichia coli genome based on DNA nanostructural probes and polyHRP enzyme. Analyst 2016;141:5304-10.

[73] Xu M, Wang R, Li Y. An electrochemical biosensor for rapid detection of E. coli O157:H7 with highly efficient bi-functional glucose oxidase-polydopamine nanocomposites and Prussian blue modified screen-printed interdigitated electrodes. Analyst 2016;141:5441-9.

[74] Brosel-Oliu S, Ferreira R, Uria N, Abramova N, Gargallo R, Muñoz-Pascual FX, et al. Novel impedimetric aptasensor for label-free detection of Escherichia coli O157:H7. Sensors Actuators B Chem 2018;255:2988-95.

[75] Ranjbar S, Shahrokhian S, Nurmohammadi F. Nanoporous gold as a suitable substrate for preparation of a new sensitive electrochemical aptasensor for detection of Salmonella typhimurium. Sensors Actuators B Chem 2018;255:1536-44.

[76] Cui F, Xu Y, Wang R, Liu H, Chen L, Zhang Q, et al. Label-free impedimetric glycan biosensor for quantitative evaluation interactions between pathogenic bacteria and mannose. Biosens Bioelectron 2018;103:94-8.

[77] Pagliarini V, Neagu D, Scognamiglio V, Pascale S, Scordo G, Volpe G, et al. Treated gold screen-printed electrode as disposable platform for label-free immunosensing of Salmonella typhimurium. Electrocatalysis 2019;10:288-94.

[78] Ye Y, Yan W, Liu Y, He S, Cao X, Xu X, et al. Electrochemical detection of Salmonella using an invA genosensor on polypyrrolereduced graphene oxide modified glassy carbon electrode and AuNPs-horseradish peroxidase-streptavidin as nanotag. Anal Chim Acta 2019;1074:80-8.

[79] Hou Y, Cai G, Zheng L, Lin J. A microfluidic signal-off biosensor for rapid and sensitive detection of Salmonella using magnetic separation and enzymatic catalysis. Food Control 2019;103: 186-93.

[80] Bagheryan Z, Raoof JB, Golabi M, Turner APF, Beni V. Diazonium-based impedimetric aptasensor for the rapid labelfree detection of Salmonella typhimurium in food sample. Biosens Bioelectron 2016;80:566-73.

[81] Sheikhzadeh E, Chamsaz M, Turner APF, Jager EWH, Beni V. Label-free impedimetric biosensor for Salmonella Typhimurium detection based on poly [pyrrole-co-3-carboxyl-pyrrole] copolymer supported aptamer. Biosens Bioelectron 2016;80:194-200.

[82] Nguyet NT, Yen LTH, Doan VY, Hoang NL, Thu VV, Ian H, et al. A label-free and highly sensitive DNA biosensor based on the core-shell structured $\mathrm{CeO}_{2}$-NR@ Ppy nanocomposite for Salmonella detection. Mater Sci Eng C 2019;96:790-7.

[83] Melo AMA, Alexandre DL, Oliveira MRF, Furtado RF, Borges MF, Ribeiro PRV, et al. Optimization and characterization of a biosensor assembly for detection of Salmonella typhimurium. J Solid State Electrochem 2018;22:1321-30.

[84] Jia F, Duan N, Wu S, Dai R, Wang Z, Li X. Impedimetric Salmonella aptasensor using a glassy carbon electrode modified with an electrodeposited composite consisting of reduced graphene oxide and carbon nanotubes. Microchim Acta 2016;183:337-44.

[85] Niyomdecha S, Limbut W, Numnuam A, Kanatharana P, Charlermroj R, Karoonuthaisiri N, et al. Phage-based capacitive biosensor for Salmonella detection. Talanta 2018;188:658-64. 
[86] Muniandy S, Teh SJ, Appaturi JN, Thong KL, Lai CW, Ibrahim F, et al. A reduced graphene oxide-titanium dioxide nanocomposite based electrochemical aptasensor for rapid and sensitive detection of Salmonella enterica. Bioelectrochemistry 2019;127:136-44.

[87] Malvano F, Pilloton R, Albanese D. A novel impedimetric biosensor based on the antimicrobial activity of the peptide nisin for the detection of Salmonella spp. Food Chemistry 2020;325:126868.

[88] Bhardwaj J, Devarakonda S, Kumar S, Jang J. Development of a paper-based electrochemical immunosensor using an antibodysingle walled carbon nanotubes bio-conjugate modified electrode for label-free detection of foodborne pathogens. Sensors Actuators B Chem 2017;253:115-23.

[89] Cihalova K, Hegerova D, Dostalova S, Jelinkova P, Krejcova L, Milosavljevic V, et al. Particle-based immunochemical separation of methicillin resistant Staphylococcus aureus with indirect electrochemical detection of labeling oligonucleotides. Anal Methods 2016;8:5123-8.

[90] Roushani M, Rahmati Z, Golchin M, Lotfi Z, Nemati M. Electrochemical immunosensor for determination of Staphylococcus aureus bacteria by IgY immobilized on glassy carbon electrode with electrodeposited gold nanoparticles. Microchim Acta 2020;187:567.

[91] Chen Q, Wang D, Cai G, Xiong Y, Li Y, Wang M, et al. Fast and sensitive detection of foodborne pathogen using electrochemical impedance analysis, urease catalysis and microfluidics. Biosens Bioelectron 2016;86:770-6.

[92] Niu X, Zheng W, Yin C, Weng W, Li G, Sun W, et al. Electrochemical DNA biosensor based on gold nanoparticles and partially reduced graphene oxide modified electrode for the detection of Listeria monocytogenes hly gene sequence. J Electroanal Chem 2017;806:116-22.

[93] Lu Y, Liu Y, Zhao Y, Li W, Qiu L, Li L. A novel and disposable enzyme-labeled amperometric immunosensor based on MWCNT fibers for Listeria monocytogenes detection. J Nanomater 2016;2016:1-8.
[94] Zhou CX, Mo RJ, Chen ZM, Wang J, Shen GZ, Li YP, et al. Quantitative label-free Listeria analysis based on aptamer modified nanoporous sensor. ACS Sens 2016;1:965-9.

[95] Huang YM, Hsu HY, Hsu CL. Development of electrochemical method to detect bacterial count, Listeria monocytogenes, and somatic cell count in raw milk. J Taiwan Inst Chem Eng 2016;62:39-44.

[96] Silva NFD, Neves MMPS, Magalhães JMCS, Freire C, DelerueMatos C. Electrochemical immunosensor towards invasionassociated protein p60: an alternative strategy for Listeria monocytogenes screening in food. Talanta 2020;216:120976.

[97] Nordin N, Yusof NA, Abdullah J, Radu S, Hushiarian R. A simple, portable, electrochemical biosensor to screen shellfish for Vibrio parahaemolyticus. AMB Exp 2017;7:41.

[98] Tam PD, Hoang NL, Lan H, Vuong PH, Anh TTN, Huy $\mathrm{TQ}$, et al. Detection of vibrio cholerae $\mathrm{O} 1$ by using cerium oxide nanowires - based immunosensor with different antibody immobilization methods. J Korean Phys Soc 2016;68: 1235-45.

[99] Mikušová Z, Farka Z, Pastucha M, Poláchová V, Obořilová R, Skládal P. Amperometric immunosensor for rapid detection of honeybee pathogen Melissococcus plutonius. Electroanalysis 2019;31:1969-76.

[100] Mishra A, Kumar J, Melo JS, Sandaka BP. Progressive development in biosensors for detection of dichlorvos pesticide: a review. J Environ Chem Eng 2021;9:105067.

[101] Bäumler AJ, Sperandio V. Interactions between the microbiota and pathogenic bacteria in the gut. Nature 2016;535:85-93.

[102] Perez-Lopez A, Behnsen J, Nuccio SP, Raffatellu M. Mucosal immunity to pathogenic intestinal bacteria. Nat Rev Immunol 2016;16:135-48.

[103] Adeel M, Mahbubur Rahman M, Caligiuri I, Canzonieri V, Rizzolio F, Daniele S. Recent advances of electrochemical and optical enzyme-free glucose sensors operating at physiological conditions. Biosens Bioelectron 2020;165:112331. 